\title{
Phenotype Switching in Metal-Tolerant Bacteria Isolated from a Hyperaccumulator Plant
}

\author{
Artur Banach 1,*iD, Agnieszka Kuźniar ${ }^{1}$ (D) Anna Marzec-Grządziel ${ }^{2} \mathbb{D}$, Anna Gałązka ${ }^{2} \mathbb{D}$ \\ and Agnieszka Wolińska ${ }^{1}$ D
}

1 Department of Biology and Biotechnology of Microorganisms, The John Paul II Catholic University of Lublin, Konstantynów St. 1 I, 20-708 Lublin, Poland; agnieszka.kuzniar@kul.pl (A.K.); agnieszka.wolinska@kul.pl (A.W.)

2 Department of Agricultural Microbiology, Institute of Soil Science and Plant Cultivation-State Research Institute, Czartoryskich 8 St., 24-100 Puławy, Poland; agrzadziel@iung.pulawy.pl (A.M.-G.); agalazka@iung.pulawy.pl (A.G.)

* Correspondence: artur.banach@kul.pl; Tel.: +48-81-454-56-48

check for updates

Citation: Banach, A.; Kuźniar, A.; Marzec-Grządziel, A.; Gałązka, A.; Wolińska, A. Phenotype Switching in Metal-Tolerant Bacteria Isolated from a Hyperaccumulator Plant. Biology 2021, 10, 879. https://doi.org/ 10.3390/biology10090879

Academic Editor: Bernard R. Glick

Received: 18 July 2021

Accepted: 28 August 2021

Published: 7 September 2021

Publisher's Note: MDPI stays neutral with regard to jurisdictional claims in published maps and institutional affiliations.

Copyright: (c) 2021 by the authors. Licensee MDPI, Basel, Switzerland. This article is an open access article distributed under the terms and conditions of the Creative Commons Attribution (CC BY) license (https:/ / creativecommons.org/licenses/by/ $4.0 /)$.
Simple Summary: Azolla filiculoides L. is an aquatic fern with the potential for degradation and accumulation of pollutants. It is accompanied by microorganisms (a microbiome) that may participate in these processes. Microorganisms showing specific phenotypes may promote plant growth in the presence of pollutants. We intended to identify such beneficial strains by studying their potential for the degradation of given organic compounds and the production of hydrolytic enzymes and phytohormones under heavy metal stress ( $\mathrm{Pb}, \mathrm{Cd}, \mathrm{Cr}(\mathrm{VI}), \mathrm{Ni}, \mathrm{Ag}$, and $\mathrm{Au}$ ). We found 10 isolates displaying varying phenotypes depending on the stress factor. The most efficient was Delftia sp., which showed potential for both degradation of organics and plant growth promotion. Other strains were more efficient at metabolizing organics or exhibited enzymatic responses in the presence of the studied metals. These identified phenotypes made all strains beneficial in both supporting plants in unfavorable conditions and degradation of organic compounds. A biopreparation containing these strains may be valuable as both a biofertilizer and a bioremediation agent.

Abstract: As an adaptation to unfavorable conditions, microorganisms may represent different phenotypes. Azolla filiculoides L. is a hyperaccumulator of pollutants, but the functions of its microbiome have not been well recognized to date. We aimed to reveal the potential of the microbiome for degradation of organic compounds, as well as its potential to promote plant growth in the presence of heavy metals. We applied the Biolog ${ }^{\mathrm{TM}}$ Phenotypic Microarrays platform to study the potential of the microbiome for the degradation of 96 carbon compounds and stress factors and assayed the hydrolytic potential and auxin production by the microorganisms in the presence of $\mathrm{Pb}, \mathrm{Cd}, \mathrm{Cr}(\mathrm{VI})$, $\mathrm{Ni}, \mathrm{Ag}$, and $\mathrm{Au}$. We found various phenotype changes depending on the stress factor, suggesting a possible dual function of the studied microorganisms, i.e., in bioremediation and as a biofertilizer for plant growth promotion. Delftia sp., Staphylococcus sp. and Microbacterium sp. exhibited high efficacy in metabolizing organic compounds. Delftia sp., Achromobacter sp. and Agrobacterium sp. were efficient in enzymatic responses and were characterized by metal tolerant. Since each strain exhibited individual phenotype changes due to the studied stresses, they may all be beneficial as both biofertilizers and bioremediation agents, especially when combined in one biopreparation.

Keywords: Azolla; heavy metals; hydrolytic enzymes; IAA; microbiome; organic pollutants

\section{Introduction}

Environmental pollution is one of the most important problems that still need to be solved. Numerous types of pollutants are released into the atmosphere, water, and soil, strongly affecting the quality of nature and human life. Therefore, there is still a need to search for new ways to mitigate and remove pollutant loads. Moreover, in order to reduce 
the human impact on the environment, measures based on natural processes are more desirable than typical techniques that consume resources and which often have negative side effects.

Microorganisms, i.e., the most abundant group of organisms, have many useful traits for coping with stress factors, including contaminants such as heavy metals (HMs) and persistent organics (POP). Nowadays, microorganisms associated with plants are arousing considerable interest. They can be present in the surroundings of plant roots (rhizobacteria) and on the surface (phylosphere) or inside their host (endoshpere). Plantmicrobial interactions are a very interesting research subject, as many of them are symbiotic, giving benefits to both partners. Moreover, plants, as primary producers, are essential for life, not only from an ecological point of view, but also as sources of food (agriculture) and useful compounds (e.g., medicinal plants). It is known that microorganisms associated with plants (the so-called plant microbiome) are able to produce many compounds, e.g., phytohormones (auxins or cytokinins), antibiotics, and enzymes (hydrolases and proteases attacking pathogens cells), which ensure plant protection against pathogens and improve plant growth and development. Such microbes are termed Plant Growth-Promoting Bacteria (PGPB) [1,2]. This ability is also observed during plant exposure to contaminants and other stress factors (e.g., temperature, drought, $\mathrm{pH}$ ); it may help plants to cope with adverse factors or even increase their potential to remove the contaminants. This is referred to as enhanced or assisted phytoremediation [3]. This emphasizes the need to study plant microbiomes to describe their role in supporting the removal of contaminants.

Environmental pressure drives the development of new traits and adaptations to altered conditions, resulting in a switch of microbial metabolisms and the formation of phenotypes adapted to the new situation. New traits have been shown to leave a fingerprint on microbial genomes. These fingerprints can be detected after short-term exposure of bacteria to stress factors by means of phenotypic platforms such as Biolog ${ }^{\mathrm{TM}}$ Phenotypic Microarrays (PMs) or simple tests showing changes in microbial enzymatic activity [4]. This information is important for the detection and understanding of changes occurring in the environment, as microorganisms participate in biogeochemical processes and element flow through each environmental compartment. In addition, resistant strains can be identified and used for bioremediation measures [5].

In aquatic ecosystems, HMs exist in many physical states, e.g., dissolved forms (free ions, complex ions, and chelated forms) and particulate forms (colloids, aggregates, precipitates, and nanoparticles) dispersed in water. In addition, they change their state at the sediment-water interface, depending on the physicochemical properties of the system. This makes them more difficult to remove via phytoremediation. HMs can be taken up via roots (soil and water) or leaves (water, air). The response of plants to the presence of metals is regulated via several phytohormones, resulting in triggering defense and response mechanisms, such as promoting the production of antioxidants and chelating compounds. However, the levels of growth stimulating auxin, cytokinins, and gibberellins decrease. In this situation, the presence of microorganisms producing these deficient compounds allows plants to cope with HMs [6,7].

We tested the potential of ten microbial genera (selected as representative genera of the whole epiphytic microbiome) to metabolize different organic contaminants that are often present in the environment and HMs, including those tested previously on Azolla sp. [8]. Based on the preliminary work [9], we hypothesized that the microorganisms would be able to synthesize the Indole-3-Acetic Acid (IAA) phytohormone and hydrolytic enzymes, namely cellulases, xylanases, and proteases at exposure to selected doses of metals studied previously. The synthesis of hydrolytic enzymes is extremely important from the point of view of colonization of plant tissues by the studied endophytes [2].

Therefore, the main intention of our study was to provide information about the potential of the microbiome to metabolize organic compounds. We also attempted to evidence its potential to produce plant-supporting substances (IAA, cellulases, xylanases, 
proteases) during exposure to $\mathrm{Pb}, \mathrm{Cd}, \mathrm{Cr}(\mathrm{VI}), \mathrm{Ni}, \mathrm{Ag}$, and $\mathrm{Au}$, which may be beneficial for plant-assisted phytoremediation.

\section{Materials and Methods}

Ten previously described and identified strains [9] were selected for the experiment. All strains were selected as representative genera of the identified microbiome of Azolla filiculoides (Table 1). Prior to the experiments, fresh cultures on agar medium were prepared from our bacterial collection.

Table 1. Strains selected for the study and their accession numbers from the GenBank database [9].

\begin{tabular}{ccc}
\hline Strain Name & Code & GenBank NO. \\
\hline Achromobacter sp. AzoEpi1 & AzoEpi1 & MG881884 \\
Bacillus sp. AzoEpi2 & AzoEpi2 & MG881885 \\
Microbacterium sp. AzoEpi6 & AzoEpi6 & MG881889 \\
Delftia sp. AzoEpi7 & AzoEpi7 & MG881890 \\
Agrobacterium sp. AzoEpi18 & AzoEpi18 & MG881901 \\
Alcaligenes sp. AzoEpi21 & AzoEpi21 & MG881904 \\
Staphylococcus sp. AzoEndo11 & AzoEndo11 & MH605511 \\
Micrococcus sp. AzoEndo7 & AzoEndo7 & MG881917 \\
Bacillus sp. AzoEndo3 & AzoEndo3 & MG859254 \\
Acinetobacter sp. AzoEndo8 & AzoEndo8 & MG881918 \\
\hline
\end{tabular}

AzoEpi indicates an epiphyte and AzoEndo denoted an endophyte.

\subsection{Phenotypic Profile Using Biolog ${ }^{T M}$ GEN III MicroPlates}

The 10 pure cultures of strains were identified and characterized using the Biolog GEN III system (Biolog Inc. Hayward, CA, USA), following the manufacturer's instructions (protocol B). This method allowed the establishment of the metabolic profile for microorganisms, i.e., a "phenotypic fingerprint". The GEN III MicroPlates ${ }^{\mathrm{TM}}$ allowed analysis of bacteria in 94 phenotypic microtests, assessing their ability to metabolize 71 carbon sources. They contained 23 chemical sensitivity assays. All necessary nutrients and biochemicals were prefilled and dried into the 96 wells of the MicroPlate. Tetrazolium redox dyes were used to indicate colorimetrically the use of the carbon sources or resistance to inhibitory chemicals. The isolates were grown on agar medium at the recommended cell density. Then, the cell suspension was inoculated into the GEN III MicroPlate ${ }^{\mathrm{TM}}, 100 \mu \mathrm{L}$ per well, and the MicroPlate was incubated to allow the phenotypic fingerprint to form. During incubation, there was increased respiration in the wells where cells used a carbon source and/or grew. Increased respiration was responsible for reduction of the tetrazolium redox dye, forming a purple color. Negative wells remained colorless, as did the negative control well (A-1) with no carbon source. There was also a positive control well (A-10) used as a reference for the chemical sensitivity assays in columns 10-12.

Bacterial colonies were transferred to inoculating fluid B (IFB) with a sterile cotton swab to generate bacterial cell suspensions, the transmittance of which was adjusted between 95 and $98 \%$ using a turbidimeter (Biolog ${ }^{\mathrm{TM}}$ ). Then, $100 \mu \mathrm{L}$ of the cell suspension was dispensed into each well. The absorbance of each well of the inoculated microplates was read at $590 \mathrm{~nm}$ on a Biolog MicroStation ${ }^{\mathrm{TM}}$ at 24-h intervals for five days. The most consistent readings came from 48-h-old Biolog plates, and these data were used in the analyses. Protocol B is used for a small number of strongly reducing species and capsulated species (primarily some strains of Aeromonas, Vibrio, and spore-forming Gram-positive rods). These species can give a false-positive result in the A-1 well with Protocol A. If this occurs, the test should be repeated using Protocol B.

\subsection{Metal Tolerance}

The tolerance of the microorganisms to $\mathrm{Pb}, \mathrm{Cd}, \mathrm{Cr}(\mathrm{VI}), \mathrm{Ni}, \mathrm{Ag}$, and $\mathrm{Au}$ was tested by determining their minimum inhibitory concentrations (MIC). Each strain was cultured in triplicate on solid nutrient agar medium supplemented with $\mathrm{Pb}\left(\mathrm{NO}_{3}\right)_{2}\left(0-1000 \mathrm{mg} \mathrm{L}^{-1}\right)$, 
$\mathrm{Cd}\left(\mathrm{NO}_{3}\right)_{2}\left(0-10 \mathrm{mg} \mathrm{L}^{-1}\right), \mathrm{K}_{2} \mathrm{Cr}_{2} \mathrm{O}_{7}\left(0-500 \mathrm{mg} \mathrm{L}^{-1}\right), \mathrm{NiCl}_{2} \cdot 6 \mathrm{H}_{2} \mathrm{O}\left(0-500 \mathrm{mg} \mathrm{L}^{-1}\right), \mathrm{AgNO}_{3}$ $\left(0-10 \mathrm{mg} \mathrm{L}^{-1}\right)$, and $\mathrm{H}\left[\mathrm{AuCl}_{4}\right]\left(0-10 \mathrm{mg} \mathrm{L}^{-1}\right)$. Doses showing distinct reduction of bacterial growth after $48 \mathrm{~h}$ of incubation were regarded as MIC.

\subsection{Synthesis of Indole-3-Acetic Acid}

The production of IAA in each treatment was conducted by cultivation of the microorganisms on liquid nutrient broth $(30 \mathrm{~mL})$ supplemented with $1 \mathrm{~g} \cdot \mathrm{L}^{-1}$ of L-tryptophan. To this end, we used 24-h cultures with cell densities set to $\mathrm{OD}_{600}$ of 1.0. The incubation was conducted in triplicate at $30^{\circ} \mathrm{C}$ for 7 days in darkness on a rotary shaker $(125 \mathrm{rpm})$. The samples were collected aseptically after $24,48,96$, and $168 \mathrm{~h}$. The collected material was centrifuged at 10,000 rpm for $10 \mathrm{~min}$, and $2 \mathrm{~mL}$ of the supernatant was mixed with $4 \mathrm{~mL}$ of Salkowski's reagent $\left(50 \mathrm{~mL} 35 \% \mathrm{HClO}_{4}, 1 \mathrm{~mL} 0.5 \mathrm{M} \mathrm{FeCl}_{3} \cdot 6 \mathrm{H}_{2} \mathrm{O}\right.$ ) [10]. After leaving the mixture at $30{ }^{\circ} \mathrm{C}$ for $30 \mathrm{~min}$ in darkness, the concentration of IAA was measured colorimetrically at $530 \mathrm{~nm}$ (Shimadzu UV/VIS-1800, Tokyo, Japan) using a calibration curve up to $100 \mu \mathrm{g} \cdot \mathrm{mL}^{-1}$. The calibration was prepared by processing the IAA solution in the same manner as the samples. The calibration was prepared by processing the IAA solution in the same manner as the samples. The development of a pink color indicated the presence of IAA.

All reagents used were dedicated for microbiological analyses and purchased from Sigma-Aldrich; water was deionized and sterilized before use $\left(\mathrm{sdH}_{2} \mathrm{O}\right)$.

\subsection{Enzymatic Assays}

The assays were conducted in a similar manner, i.e., a 24-h strain suspension $(30 \mu \mathrm{L}$, $\mathrm{OD}_{600}$ of 1.0) was poured in triplicate onto a Petri dish with solid nutrient agar medium supplemented with the doses of the tested metals and a substrate characteristic for a given test (test medium). Before pouring the medium on the plates, the $\mathrm{pH}$ was set to 7.2.

\subsubsection{Cellulolytic Activity}

The ability of the strains to produce cellulase was assayed by cultivation of the microorganisms on the test medium supplemented with $1 \%(w / v)$ carboxymethylcellulose sodium salt (CMC) at $30^{\circ} \mathrm{C}$ for $48 \mathrm{~h}$. The activity was checked by flooding each plate with Lugol's solution. The occurrence of clear yellow zones around the colonies against the black background indicated the potential of the strain for degradation of cellulose [9].

\subsubsection{Xylanolytic Activity}

The xylanase assay consisted of supplementation of the test medium with $1 \%(w / v)$ of xylan. Next, the samples were incubated at $30^{\circ} \mathrm{C}$ for $48 \mathrm{~h}$ and Lugol's solution was used to visualize the presence of clear zones around the colonies. The sizes of the zones were recorded and used as a measure of xylanolytic activity [11].

\subsubsection{Proteolytic Activity}

To detect proteases, the test medium was supplemented with 5\% skimmed milk. After $48 \mathrm{~h}$ of incubation at $30^{\circ} \mathrm{C}$ in the dark, the appearance of clear zones around the colonies indicated proteolytic activity [9].

The sizes of decolorization zones (halos) were used as a measure of given enzymatic activity in all tests.

\subsection{Statistical Procedures}

All experiments were performed in triplicate, except for the Biolog GEN III assays. All relative values are presented as means \pm standard deviation (SD). The data from Biolog GEN III experiments were combined in a single matrix, represented as a positive integer, OmniLog ${ }^{\mathrm{TM}}$ units (OL units). To illustrate the Biolog results and metabolic profiles, the similarity patterns of the use of the organic compounds and chemical sensitivity assays between all the strains are presented based on individual heatmap graphs. The 
AWCD of all the strains were calculated, where AWCD was the sum of the differences between the OL units of the blank well (water) and substrate wells divided by 95 (the number of substrate wells in the GEN III MicroPlates ${ }^{\mathrm{TM}}$ ), after $48 \mathrm{~h}$ of incubation. For the substrates, Shannon diversity $\left(\mathrm{H}^{\prime}\right)$ and Shannon evenness (E) indices were also assessed. A multivariate statistical method using PCA was performed to summarize the variability of the tested strains and to determine the association among the measured activities. For Spearman's rank correlation, PCA, and heatmap analysis, all the data were standardized so that each score contributed equally to the analysis. MANOVA was used to test the effect of the metals and their doses on bacterial enzymatic activity and phytohormone synthesis. One-way ANOVA was used to check the significance of the differences of AWCD for each group of compounds/conditions for the strains. For both tests, Tukey's post hoc procedure was used to assess the differences between the groups. Normality and equality of variances were examined using Shapiro-Wilk and Levene's statistics, respectively. The significance was assumed at $p<0.05$. All these analyses were performed using Statistica 13.1 (StatSoft. Inc., Tulsa, OK, USA).

\section{Results}

\subsection{Phenotypic Characterization of Bacteria Using BiologTM GEN III MicroPlates}

The GEN III MicroPlates ${ }^{\mathrm{TM}}$ analysis based on average well color density (AWCD) revealed the characteristic metabolic pattern (metabolic fingerprint) of the studied microorganisms during their aerobic metabolism. There were 61 types of carbon sources in the GEN III MicroPlates ${ }^{\mathrm{TM}}$, including carbohydrates (28 types), carboxylic acids (22 types), and amino acids (11 types) (Figure 1). The metabolic activity of the analyzed strains demonstrated significant differences in the rates of use of the carbon sources $(p=0.0001$; Figures 1 and 2). The following order of carbon source use rates was exhibited by the studied bacteria: amino acids $>$ carboxylic acids $>$ carbohydrates. Thus, amino acids were the major carbon sources used by the 10 bacterial strains, while carboxylic acids and carbohydrates were definitely used less efficiently. The statistical analysis showed significant differences in carbohydrate metabolism between the tested bacterial strains $(p=0.000001)$. However, there were no statistically significant differences in the metabolism of amino acids between the tested strains isolated from Azolla tissues $(p=0.05662)$. A detailed analysis of the AWCD variation indicated that the carboxylic acid metabolizing activity of the Micrococcus sp. AzoEndo7 and Staphylococcus sp. AzoEndo11 strains was definitely lower than in the other strains tested. Noteworthy is the carbon metabolism of the Delftia sp. AzoEpi7 strain, which uses carboxylic acids and amino acids much more easily than carbohydrates (Figures 1 and 2).

The phenotypic microarrays identified the differences between the species on the basis of growth at different $\mathrm{pH}$, salinity, assimilation of substrates (for example surfactants, dyes, some toxic ions), and sensitivity to antibiotics. The results obtained revealed that the studied microorganisms varied in their susceptibility to all the antimicrobials. All isolates were $100 \%$ susceptible to rifamycin SV and showed low resistance to fusidic acid (Figure 3a). Moreover, all of the isolated bacteria were resistant to aztreonam after incubation for $48 \mathrm{~h}$. Delftia sp. AzoEpi7 showed the ability to metabolize the lincomycin and vancomycin antibiotics. Among the bacteria tested, the Micrococcus sp. AzoEndo7 and Staphylococcus sp. AzoEndo11 showed the lowest ability to metabolize the drugs tested (Figure 3b).

Except for the Achromobacter sp. AzoEpi1, Microbacterium sp. AzoEpi6, and Acinetobacter sp. AzoEndo8, the studied bacteria had the lowest potential to metabolize N-acetylneuraminic acid. The highest metabolic activity at $30{ }^{\circ} \mathrm{C}$ for $48 \mathrm{~h}$ was demonstrated by the tested strains (except for Alcaligenes sp. AzoEpi21, Staphylococcus sp. AzoEndo11, and Bacillus sp. AzoEndo3) in the case of guanidine HCl. Furthermore, Achromobacter sp. AzoEpi1, Bacillus sp. AzoEpi2, Microbacterium sp. AzoEpi6, Agrobacterium sp. AzoEpi18, and Acinetobacter sp. AzoEndo8 exhibited metabolic activity against all tested compounds. 


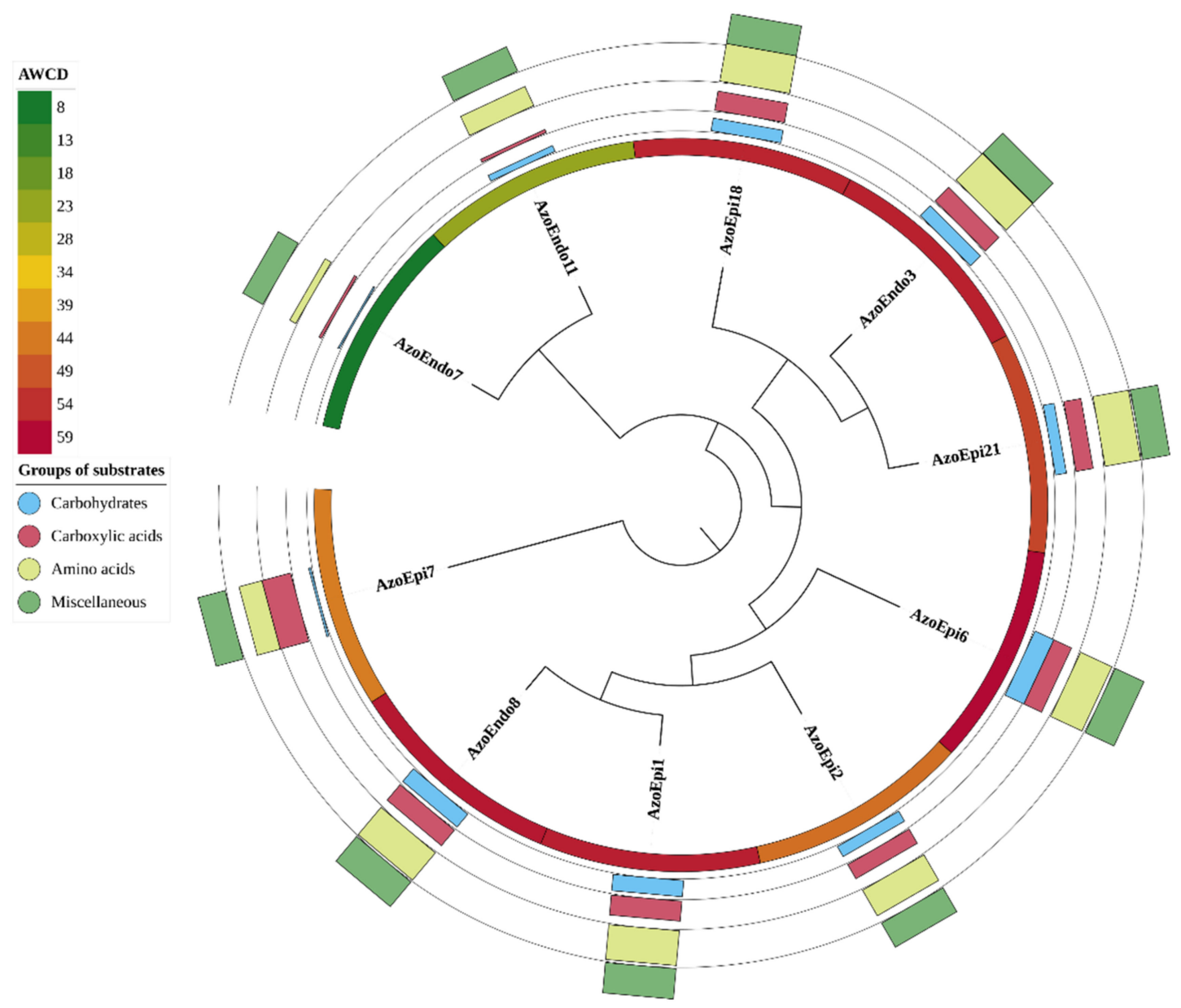

Figure 1. Phenotyping analysis of the studied microorganisms based on the results of GEN III MicroPlates ${ }^{\mathrm{TM}}$ analysis. Clustering analysis tree created on the basis of the results of the use of all substrates after the correction with negative reaction control (UPGMA, Euclidean similarity index). Inner circle (color gradient) presents AWCD-average well color development. Multivalued bar charts present the percent use of different groups of substrates: carbohydrates, carboxylic acid, amino acids, and miscellaneous (each line presents a different group of substrates, as shown in the legend).

The metabolic activity of the strains against the tested surfactants and dyes was low. Among the studied bacteria, only Micrococcus sp. AzoEndo7 and Delftia sp. AzoEpi7 showed metabolic activity against Niaproof 4 . In contrast, Tween 40 was metabolized by most bacteria with different degrees of intensity, except for the Staphylococcus sp. AzoEndo11. Achromobacter sp. AzoEpi1, Bacillus sp. AzoEpi2, and Microbacterium sp. AzoEpi6 exhibited no ability to metabolize the tested dyes during growth in aerobic conditions at a temperature of $30^{\circ} \mathrm{C}$ (Figure 3c).

The Bacillus sp. AzoEndo3, Micrococcus sp. AzoEndo7, Staphylococcus sp. AzoEndo11, Delftia sp. AzoEpi7, Agrobacterium sp. AzoEpi18, and Agrobacterium sp. AzoEpi21 displayed the lowest potential to use the tested organic compounds. The GEN III MicroPlates ${ }^{\mathrm{TM}}$ analysis showed that $1 \%$ sodium lactate was most actively metabolized by the tested strains. The phenotypic microarrays revealed the lowest potential of the bacteria tested to metabolize D-Glucose-6- $\mathrm{PO}_{4}$ (Figure 3c). The GEN III MicroPlates ${ }^{\mathrm{TM}}$ analysis evidenced that all the tested bacteria were able to grow at $\mathrm{pH}$ 6. In turn, the endophytes Staphylococcus sp. AzoEndo11 and Micrococcus sp. AzoEndo7 were able to grow at pH 5 (Figure 3d). The analysis of the entire salinity set on the GEN III MicroPlates ${ }^{\mathrm{TM}}(1-8 \% \mathrm{NaCl})$ demonstrated a clear pattern of preference of consumption of multiple sodium chloride solutions in aerobic conditions by the tested bacteria. A slight decrease in growth was noted at the concentration of $4 \%$ and $8 \% \mathrm{NaCl}$ for the Delftia sp. AzoEpi7 (Figure 3d). 

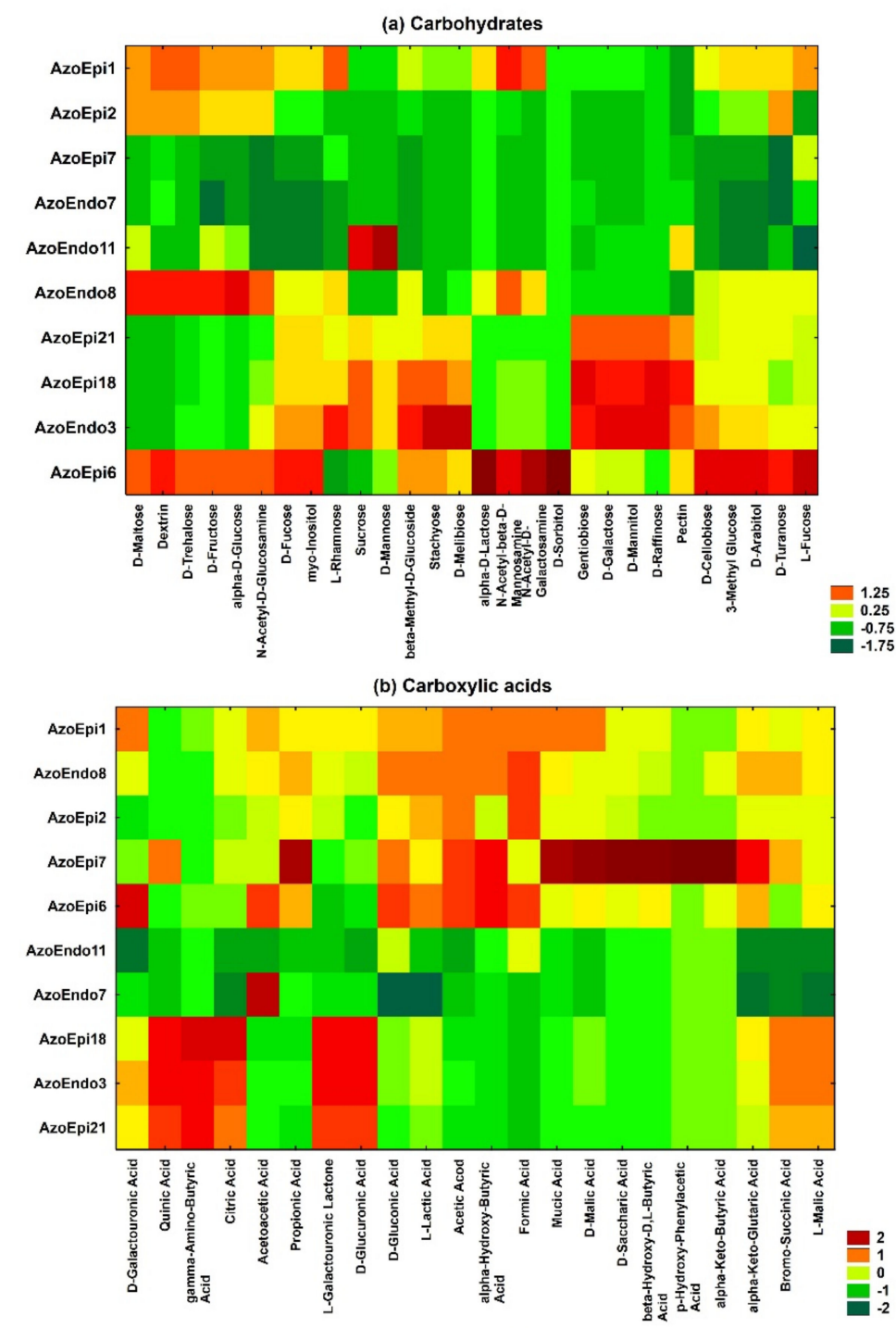

(c) Amino acids

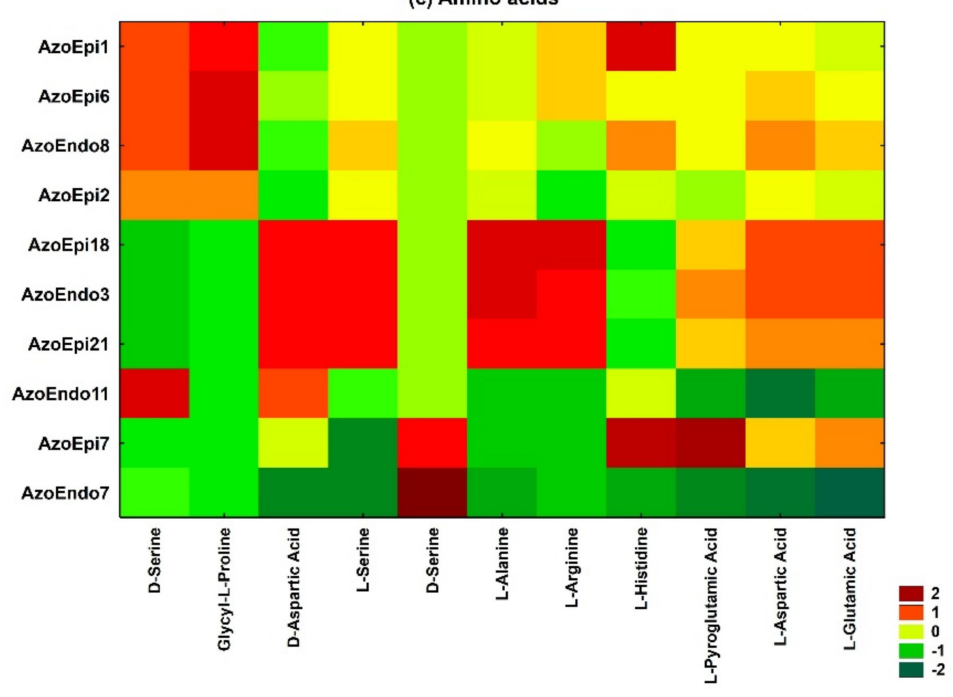

Figure 2. Heatmap of 10 strains showing metabolic profiles for (a) carbohydrates, (b) carboxylic acid, and (c) amino acids after $48 \mathrm{~h}$ of incubation. The relative use of selected substrates is depicted by color intensity, based on the legend next to the figure. The highest and lowest consumption rates are indicated by red and green colors, respectively. 

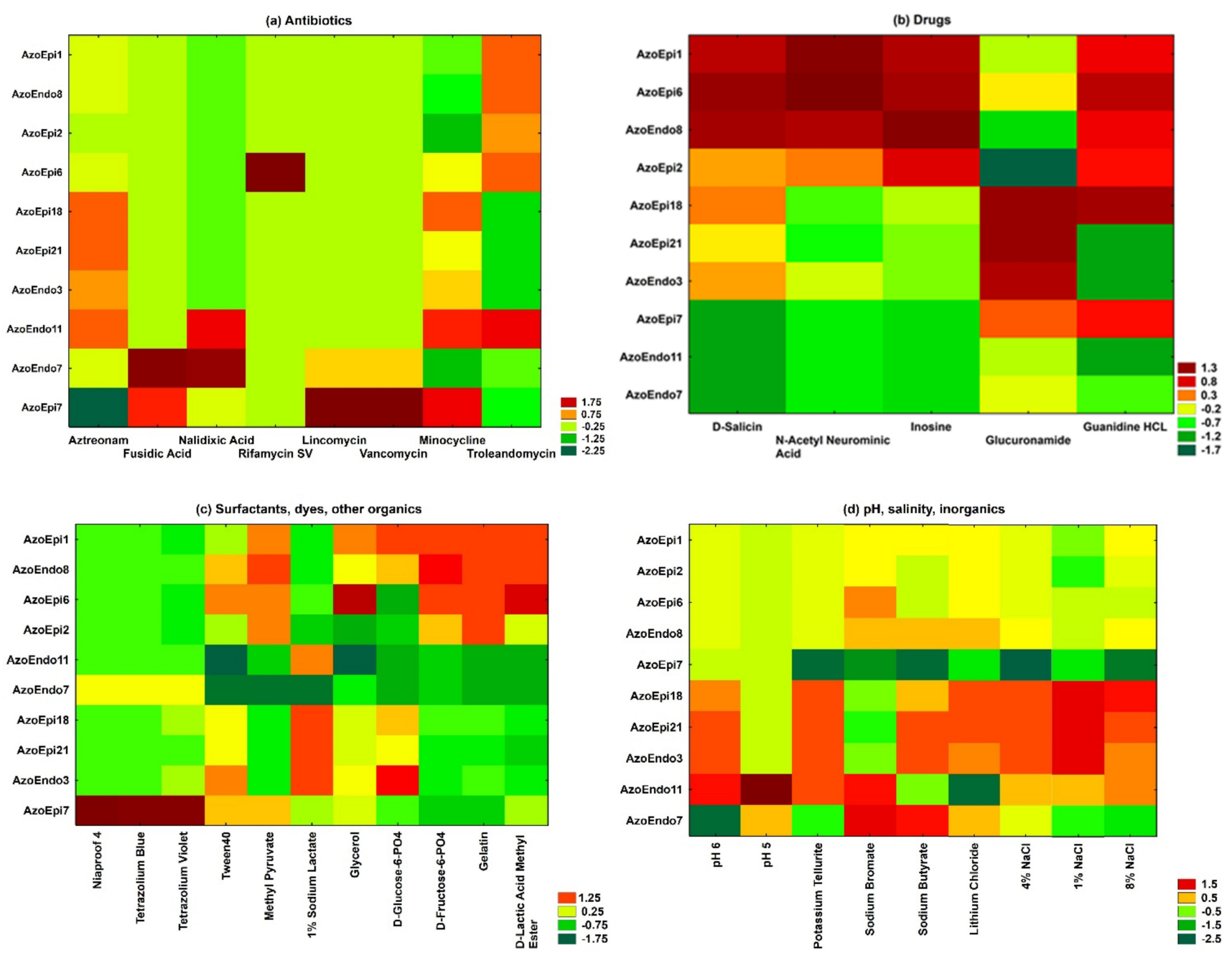

Figure 3. Heatmap of 10 strains showing metabolic profiles for some compounds: (a) antibiotics, (b) drugs, and (c) surfactants, dyes, and other organics, as well as (d) $\mathrm{pH}$, salinity, and inorganics after $48 \mathrm{~h}$ of incubation. The relative use of selected substrates is depicted by color intensity, based on the legend next to the figure. The highest and lowest consumption rates are indicated by red and green color, respectively.

The phenotypic microarrays identified the differences in the profiles between the species in terms of growth in the presence of some ions: lithium chloride, potassium tellurite, sodium butyrate, and bromate. The GEN III MicroPlates ${ }^{\mathrm{TM}}$ analysis showed low activity of the Delftia sp. AzoEpi7 to metabolize all these inorganic compounds in aerobic conditions. In turn, high metabolic activity in aerobic conditions was detected in the Micrococcus sp. AzoEndo7 (Figure 3d).

The principal component analysis (PCA) evidenced that PC1 and PC2 extracted from the 94 factors (71 carbon sources and 23 susceptibility factors present on the GenIII MicroPlates ${ }^{\mathrm{TM}}$ ) explain $36.33 \%$ and $29.52 \%$ of the variable variance, respectively, with a rather high cumulative variance contribution rate of 65.85 . PCA revealed distinct differences in the metabolic use of the studied compounds between the strains isolated from Azolla sp. On this basis, three groups with a different metabolic profile were distinguished, which reflected different structures and characteristics of metabolic activity. As shown in Figure 4, the first group formed the following strains: Microbacterium sp. AzoEpi6, Acinetobacter sp. AzoEndo8, Achromobacter sp. AzoEpi1, Bacillus sp. AzoEpi2, and Delftia sp. AzoEpi7 with a positive correlation. The second group of strains, Bacillus sp. AzoEndo3, Alcaligenes sp. AzoEpi21, and Agrobacterium sp. AzoEpi18, were located on the negative side of PC2, and the first and third group of strains (Micrococcus sp. AzoEndo7 and 
Staphylococcus sp. AzoEndo11) were located on the different sides of PC1. Noteworthy, the Delftia sp. AzoEpi7 strain was characterized by a different metabolic profile than the metabolic profiles of the strains divided into three groups. These strains were located on the positive side of PC1 and PC2 as the four groups with the specific metabolisms profile.

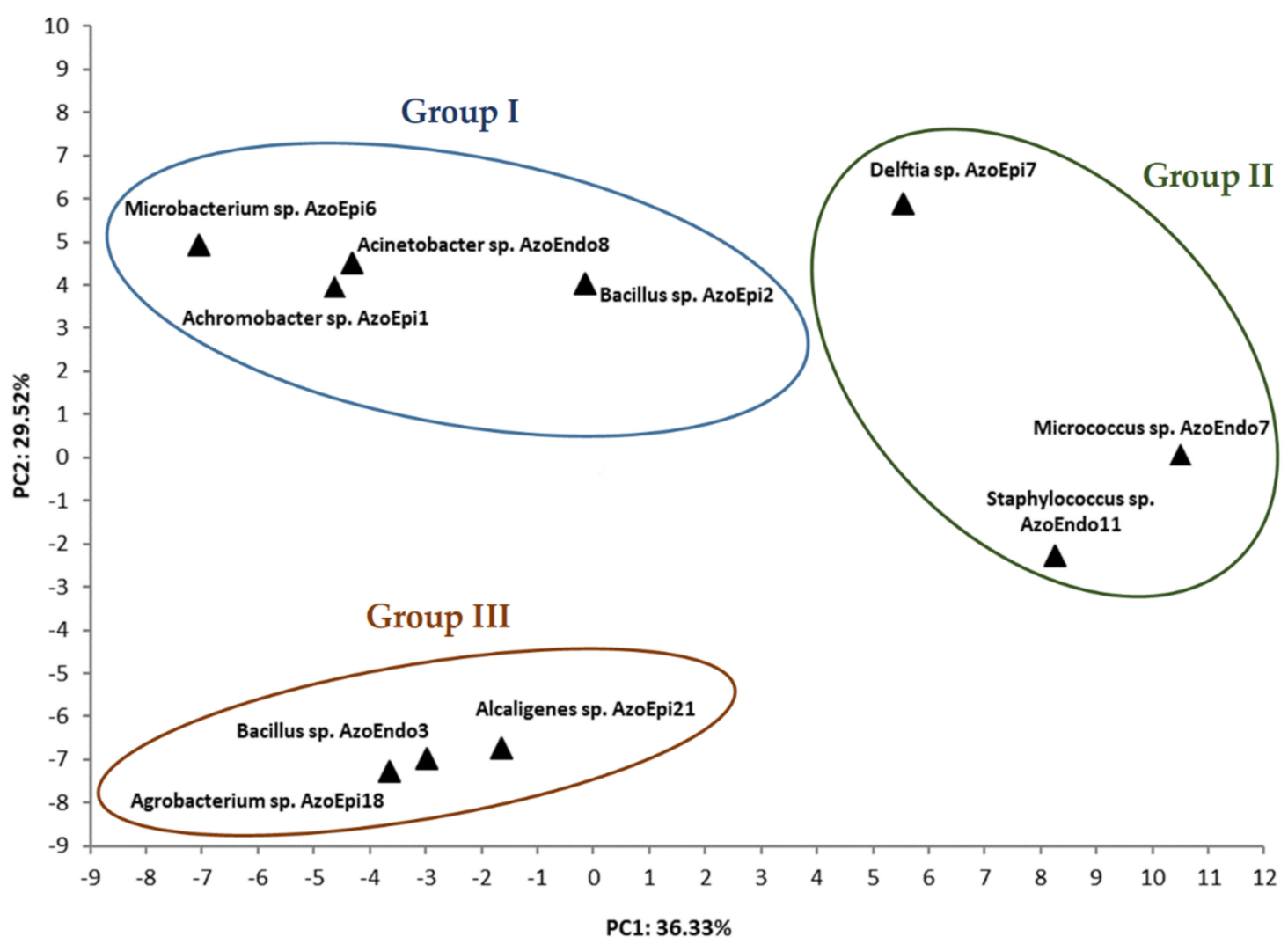

Figure 4. Principal components analysis (PCA) of the Biolog GEN III system for the studied strains after 48h of incubation at $30{ }^{\circ} \mathrm{C}$ on GEN III MicroPlates TM; Principal Component 1 (PC1) plotted against Principal Component 2 (PC2) generated by PCA shows the different patterns of 71 carbon sources and 23 susceptibility factors in the studied microorganisms.

\subsection{Tolerance of Microorganisms to Heavy Metals}

The studied strains exhibited various levels of tolerance to the selected metals (Table 2). Agrobacterium sp. AzoEpi18 appeared to be the most resistant isolate growing unaffected at all concentrations of the metals with the exception of the highest dose of $\mathrm{Pb}$. Similarly, Achromobacter sp. AzoEpi1 showed the highest resistance (all doses of 5 metals) except for $10 \mathrm{mg} \mathrm{Au} \mathrm{L}{ }^{-1}$. The next level of resistance (4 out of 6 metals) was exhibited by Microbacterium sp. AzoEpi6 (affected by Ni and Au), Alcaligenes sp. AzoEpi21 (reduced growth at $200 \mathrm{mg} \mathrm{L}^{-1} \mathrm{~Pb}$ and $\mathrm{Au}$ ), Acinetobacter sp. AzoEndo8 (lower growth at $\mathrm{Cd}$ and $\mathrm{Au}$ ), and Delftia sp. AzoEpi7 (growth only at $0.5 \mathrm{mg} \mathrm{L}^{-1} \mathrm{Cd}$ and up to $200 \mathrm{mg} \mathrm{L}^{-1} \mathrm{~Pb}$ ). The other isolates were influenced by $\mathrm{Pb}, \mathrm{Cd}, \mathrm{Ni}$, and $\mathrm{Au}$-both Bacillus sp. isolates tolerated the full ranges of $\mathrm{Cr}$ and $\mathrm{Ag}$ doses, while Staphylococcus sp. AzoEndo11 and Micrococcus sp. AzoEndo7 were the most sensitive. The former grew in the whole range of $\mathrm{Cd}$ and $\mathrm{Ag}$, while the latter grew only in the full range of the Ag doses. It can be concluded that all the bacteria grew well in the Ag treatment, and eight strains, the exceptions being Staphylococcus sp. AzoEndo11 and Micrococcus sp. AzoEndo7, grew efficiently in the Cr (VI) treatment. 
Table 2. MIC for each treatment.

\begin{tabular}{ccccccc}
\hline Strain & $\mathbf{P b}$ & $\mathbf{C d}$ & $\mathbf{C r}$ & $\mathbf{N i}$ & $\mathbf{A g}$ & $\mathbf{A u}$ \\
\hline Achromobacter sp. AzoEpi1 & 1000 & 10 & 100 & 100 & 10 & 5 \\
Bacillus sp. AzoEpi2 & 500 & 5 & 100 & 50 & 10 & 5 \\
Microbacterium sp. AzoEpi6 & 1000 & 10 & 100 & 50 & 10 & 5 \\
Delftia sp. AzoEpi7 & 200 & 0.5 & 100 & 100 & 10 & 10 \\
Agrobacterium sp. AzoEpi18 & 500 & 10 & 100 & 100 & 10 & 10 \\
Alcaligenes sp. AzoEpi21 & 200 & 10 & 100 & 100 & 10 & 5 \\
Staphylococcus sp. AzoEndo11 & 500 & 10 & 50 & 50 & 10 & 5 \\
Micrococcus sp. AzoEndo7 & 500 & 5 & 50 & 50 & 10 & 5 \\
Bacillus sp. AzoEndo3 & 1000 & 5 & 100 & 50 & 10 & 5 \\
Acinetobacter sp. AzoEndo8 & 1000 & 5 & 100 & 100 & 10 & 5 \\
\hline
\end{tabular}

Despite the lower tolerance of some isolates, we decided to determine their enzymatic activities and IAA production in the full range of metal doses to check their metabolism in very unfavorable conditions.

\subsection{Synthesis of IAA under Heavy Metal Stress}

Among the isolates, only Delftia sp. AzoEpi7 and Agrobacterium sp. AzoEpi18 were able to produce IAA in natural conditions. Initially, Delftia sp. synthesized $9.71 \mu \mathrm{g} \mathrm{mL}^{-1}$ versus $22.26 \mu \mathrm{g} \mathrm{mL}^{-1}$ of IAA produced by Agrobacterium sp. With time, these levels declined in the latter strain to $12.89 \mathrm{\mu g} \mathrm{mL}^{-1}$ and we did not record any phytohormone after $96 \mathrm{~h}$ at the end of the experiment. In the case of Delftia sp., after a strong decrease to $1.46 \mu \mathrm{g} \mathrm{mL}^{-1}$, this isolate started to produce more IAA up to $16.69 \mu \mathrm{g} \mathrm{mL} \mathrm{m}^{-1}$ at $77 \mathrm{~h}$ followed by a decline to $8.12 \mu \mathrm{g} \mathrm{mL}^{-1}$ at the end of experiment (Figure 5).

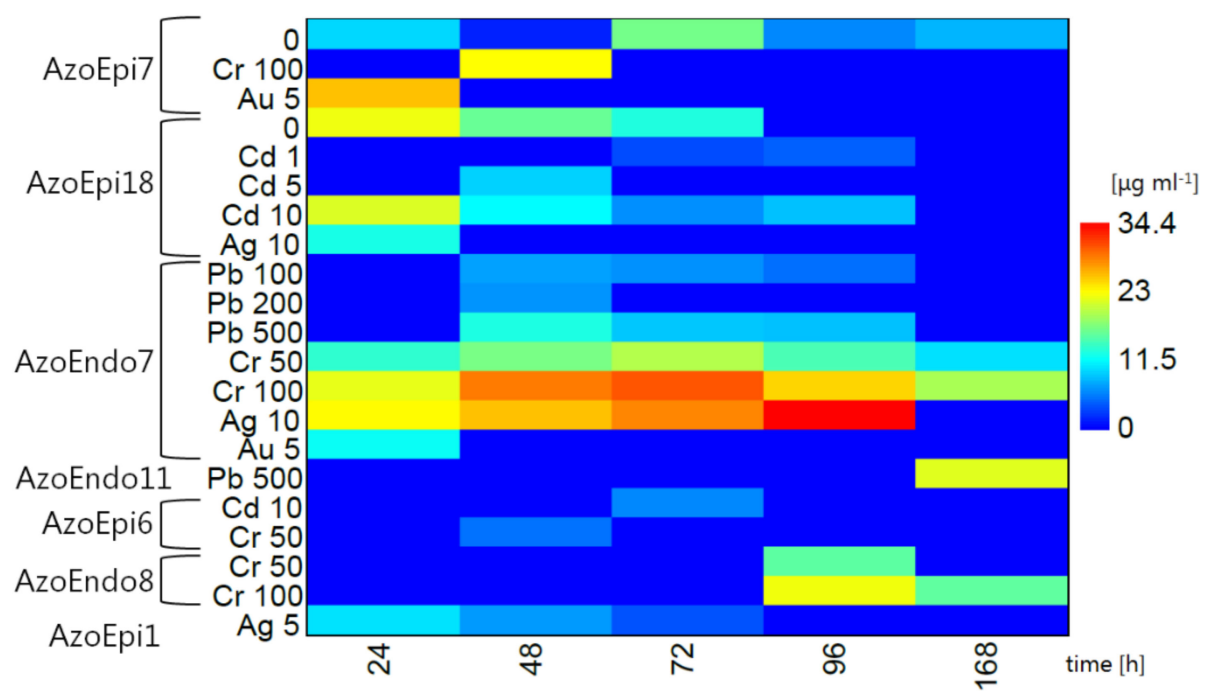

Figure 5. IAA production by the studied isolates under various treatments over time.

The response of the isolates to heavy metals was reflected in various levels of IAA production; some strains released IAA, even though they did not produce this phytohormone in the control treatment. In the presence of $\mathrm{Ni}$, no isolates were able to produce IAA.

Upon exposure to Pb, only Micrococcus sp. AzoEndo7 and Staphylococcus sp. AzoEndo11 showed IAA production. The former strain showed a similar pattern at 100 and $500 \mathrm{mg} \mathrm{Pb} \mathrm{L}^{-1}$ the IAA production started at 7.24 and $12.80 \mu \mathrm{g} \mathrm{mL}^{-1}$ after $48 \mathrm{~h}$ and decreased for the next $48 \mathrm{~h}$ to 4.98 and $8.66 \mu \mathrm{g} \mathrm{mL}^{-1}$, respectively. After the exposure to $200 \mathrm{mg} \mathrm{Pb} \mathrm{L}^{-1}$, these microorganisms produced IAA only after $48 \mathrm{~h}\left(6.65 \mu \mathrm{g} \mathrm{mL}^{-1}\right)$. In the case of Staphylococcus sp., it took $168 \mathrm{~h}$ to produce IAA, but a high IAA level of $21.55 \mu \mathrm{g} \mathrm{mL}{ }^{-1}$ was achieved (Figure 5). 
Since $1000 \mathrm{mg} \mathrm{Pb} \mathrm{L}^{-1}$ strongly affected most strains (Table 1), we did not record any IAA evolution in this treatment.

In the case of the Cd treatment, only Agrobacterium sp. AzoEpi18 and Microbacterium sp. AzoEpi6 were able to produce IAA. No IAA was detected at the lowest dose of Cd. Microbacterium sp. synthesized $6.19 \mathrm{\mu g} \mathrm{mL}^{-1}$ of the phytohormone only after $72 \mathrm{~h}$ at the highest dose of Cd. IAA production by Agrobacterium sp. was recorded in the presence of 1-10 $\mathrm{mg} \mathrm{Cd} \mathrm{L}^{-1}$ and was linearly related to the metal dose. The lowest levels of IAA (up to $\left.4.35 \mu \mathrm{g} \mathrm{mL}^{-1}\right)$ were recorded at $1 \mathrm{mg} \mathrm{Cd} \mathrm{L}^{-1}$ followed by $9.46 \mu \mathrm{g} \mathrm{mL}^{-1}\left(5 \mathrm{mg} \mathrm{Cd} \mathrm{L}^{-1}\right)$, and the highest and longest observed (up to $96 \mathrm{~h}$ ) yield was noted at $10 \mathrm{mg} \mathrm{Cd} \mathrm{L}^{-1}$ (on average $11.97 \mathrm{~g} \mathrm{~mL}^{-1}$ ). The latter treatment showed initially a high IAA concentration of $21.34 \mu \mathrm{g} \mathrm{mL}^{-1}$, which further decreased to $8.70 \mu \mathrm{g} \mathrm{mL}^{-1}$ (Figure 5).

During the exposure to $\mathrm{Cr}(\mathrm{VI})$ ions, four isolates were able to synthesize IAA, namely Acinetobacter sp. AzoEndo8, Micrococcus sp. AzoEndo7 (both in the whole range of the metal dose), Delftia sp. AzoEpi7 (100 mg Cr L $\left.{ }^{-1}\right)$, and Microbacterium sp. AzoEpi6 (50 mg Cr L $\left.{ }^{-1}\right)$. In the case of Acinetobacter sp., it took $96 \mathrm{~h}$ to initiate the production of the phytohormone$15.65 \mu \mathrm{g} \mathrm{mL}^{-1}$ (lower dose) and up to $22.38 \mu \mathrm{g} \mathrm{mL}^{-1}$ (higher dose). Micrococcus sp. was very efficient in the release of IAA, as we observed production of the phytohormone throughout the experiment (168 h in total). At $50 \mathrm{mg} \mathrm{Cr} \mathrm{L}{ }^{-1}$, the concentration of the phytohormone was in the range of $10.13-19.54 \mu \mathrm{g} \mathrm{mL}{ }^{-1}$ with a maximum at $72 \mathrm{~h}$. In the case of the higher metal dose, the amount of IAA ranged between 19.12 and $30.59 \mu \mathrm{g} \mathrm{mL}^{-1}$ with a maximum in the middle of the experiment as well. The efficiency of Delftia sp. in the synthesis was also high $\left(22.93 \mu \mathrm{g} \mathrm{mL}{ }^{-1}\right)$, but it was recorded only after $48 \mathrm{~h}$ at $100 \mathrm{mg} \mathrm{Cr} \mathrm{L}^{-1}$. The weakest production of IAA was noted in the case of Microbacterium sp., where the concentration amounted to $5.15 \mu \mathrm{g} \mathrm{mL}^{-1}$ after $48 \mathrm{~h}$ at the onset of the experiment (Figure 5).

Three strains produced the phytohormone after the exposure to Ag. Achromobacter sp. AzoEpi1 displayed continuous synthesis of IAA decreasing from 10.21 to $3.68 \mu \mathrm{g}$ $\mathrm{mL}^{-1}$ during $72 \mathrm{~h}$ of the experiment at $5 \mathrm{mg} \mathrm{Ag} \mathrm{L}^{-1}$. In the presence of $10 \mathrm{mg} \mathrm{Ag} \mathrm{L}^{-1}$, Agrobacterium sp. AzoEpi18 released $12.59 \mu \mathrm{g} \mathrm{mL}{ }^{-1}$ of IAA only during the first $24 \mathrm{~h}$ of the metal stress. The most efficient was Micrococcus sp. AzoEndo7 showing continuous and increasing synthesis of IAA in the range of $23.10-34.44 \mu \mathrm{g} \mathrm{mL}^{-1}$ during $96 \mathrm{~h}$ of the experiment (Figure 5).

Au had a negative impact on the studied microbiome; only two strains synthesized IAA at $5 \mathrm{mg} \mathrm{Au} \mathrm{L}{ }^{-1}$, namely Delftia sp. AzoEpi7 (25.77 $\left.\mu \mathrm{g} \mathrm{mL}^{-1}\right)$ and Micrococcus sp. AzoEndo7 $\left(11.92 \mu \mathrm{g} \mathrm{mL}^{-1}\right)$, both only during the first $24 \mathrm{~h}$ of the experiment (Figure 5).

To summarize, this experiment revealed that Micrococcus sp. AzoEndo7 was the most efficient strain in IAA synthesis, as it was able to produce the phytohormone at the exposure to three metals (seven treatments in total). The second most efficient strain was Agrobacterium sp. AzoEpi18 (control and two metals, five treatments). The lowest performance was recorded for Staphylococcus sp. AzoEndo11 and Achromobacter sp. AzoEpi1 (one treatment). It is also interesting that Micrococcus sp. was very efficient in IAA production at $100 \mathrm{mg} \mathrm{Cr} \mathrm{L}^{-1}$ even though this dose of metal had a negative impact on its growth (Table 1).

\subsection{Cellulolytic Activities in the Presence of Heavy Metals}

As all non-treated strains exhibited activities of cellulases, xylanases, and proteases, we focused on the analysis of differences between activities (respectively: $C M C_{\text {diff }}, X Y L_{\text {diff }}$ and PROT $_{\text {diff }}$ ) for a given metal treatment and appropriate values for the non-treated strain. We present these data as means with minimum and maximum values.

In the case of $\mathrm{Pb}$, all the epiphytes showed significantly higher mean $\mathrm{CMC}_{\text {diffs }}$ values than the endophytes $(p<0.001$, Figure 6). In most cases, cellulase activity was stimulated in the presence of $\mathrm{Pb}$; we only recorded slightly smaller halos in some treatments of Achromobacter sp. AzoEpi1, Bacillus sp. AzoEndo3, Micrococcus sp. AzoEndo7, Acinetobacter sp. AzoEndo8, and Staphylococcus sp. AzoEndo11. Delftia sp. AzoEpi7 and 
Agrobacterium sp. AzoEpi18 were the most efficient strains in cellulose degradation, while Micrococcus sp. AzoEndo7 was the least efficient (Supplementary Figure S1). In the presence of $\mathrm{Cd}, 8$ strains displayed stimulation of cellulose degradation, compared to the control $\left(\mathrm{CMC}_{\text {diff }}=1.17-10.67 \mathrm{~mm}\right)$; only Bacillus sp. AzoEndo3 and Staphylococcus sp. AzoEndo11 showed smaller decolorization zones resulting in $\mathrm{CMC}_{\text {diff }}=-1.17$ and $-6.17 \mathrm{~mm}$, respectively $(p<0.01$, Figure 6$)$. The strongest activities were recorded for Microbacterium sp. AzoEpi6 and Delftia sp. AzoEpi7 (all doses of Cd), while strong inhibition of cellulase was achieved by Staphylococcus sp. AzoEndo11 (all doses of metal, Supplementary Figure S1). The exposure to $\mathrm{Cr}$ revealed two equal groups of strains: five with positive $\mathrm{CMC}_{\text {diffs }}$ (Achromobacter sp. AzoEpi1, Bacillus sp. AzoEpi2, Microbacterium sp. AzoEpi6, Delftia sp. AzoEpi7, and Acinetobacter sp. AzoEndo8) and five showing decreased cellulase activity (Agrobacterium sp. AzoEpi18, Alcaligenes sp. AzoEpi21, Bacillus sp. AzoEndo3, Micrococcus sp. AzoEndo7, and Staphylococcus sp. AzoEndo11) $(p<0.01$, Figure 6). In the case of Alcaligenes sp. AzoEpi21, $50 \mathrm{mg} \mathrm{Cr} \mathrm{L}^{-1}$ led to reduction of cellulose degradation, which was significantly higher at $100 \mathrm{mg} \mathrm{Cr} \mathrm{L}^{-1}(p<0.001)$. In the case of the other strains, we did not record any significant effect of the metal dose. Again, Microbacterium sp. AzoEpi6 and Delftia sp. AzoEpi7 were the most efficient strains in cellulose degradation at the exposure to $\mathrm{Cr}$, whereas the most inhibiting response was recorded for Micrococcus sp. AzoEndo7 (Supplementary Figure S1). Ni had a negative effect on cellulase activity, as only 4 strains out of 10 (Achromobacter sp. AzoEpi1, Bacillus sp. AzoEpi2, Delftia sp. AzoEpi7, and Micrococcus sp. AzoEndo7) exhibited $\mathrm{CMC}_{\text {diffs }}>0(p<0.001$, Figure 6). Micrococcus sp. AzoEndo7 was the most efficient with the highest $\mathrm{CMC}_{\text {diff }}$ of $21 \mathrm{~mm}$ at $50 \mathrm{mg} \mathrm{Ni} \mathrm{L}^{-1}$, while Acinetobacter sp. AzoEndo8 showed the highest inhibition of cellulolytic activity $\left(\mathrm{CMC}_{\text {diff }}=-10.3 \mathrm{~mm}\right.$, both Ni doses) (Supplementary Figure S1). Both noble metals strongly inhibited the potential of the studied strains for cellulose degradation (Figure 6). In the case of Ag, only Microbacterium sp. AzoEpi6 and Delftia sp. AzoEpi7 had positive $\mathrm{CMC}_{\text {diffs }}$ (on average 5 and $11.7 \mathrm{~mm}$, respectively, $p<0.01$ ). The strongest inhibition of cellulase was recorded for Achromobacter sp. AzoEpi1, Acinetobacter sp. AzoEndo8, and Staphylococcus sp. AzoEndo11 ( $\mathrm{CMC}_{\text {diff }}$ ranging between -5 and $-8 \mathrm{~mm}$ ) (Supplementary Figure S1). During the exposure to Au, only Delftia sp. AzoEpi7 exhibited stimulated cellulolytic activity $\left(\mathrm{CMC}_{\text {diff }}=8-11 \mathrm{~mm}, p<0.001\right)$. The strongest inhibition of this activity in relation to the control was noted for Micrococcus sp. AzoEndo7 and Staphylococcus sp. AzoEndo11 at $10 \mathrm{mg} \mathrm{Au} \mathrm{L}^{-1}$ (Supplementary Figure S1).

Our analysis of cellulolytic activity allowed us to arrange the isolates from the most resistant, i.e., active under heavy metal stress, to the most sensitive, which represents phenotype shifting towards both resistance and sensitivity. The strongest activity was exhibited by Delftia sp. AzoEpi7 showing stimulation of cellulose degradation $\left(\mathrm{CMC}_{\text {diff: }}\right.$ : $7.0-16.7 \mathrm{~mm}$ ) in all metal treatments (the weakest at $\mathrm{Ni}$ ), followed by Microbacterium sp. AzoEpi6 (five metals, $\mathrm{CMC}_{\text {diff: }}$ : $1.3-14.7 \mathrm{~mm}$, a negative effect of one dose of $\mathrm{Ni}$ ), Bacillus sp. AzoEpi2 (four metals, $\mathrm{CMC}_{\text {diff: }}: 0.7-10.3 \mathrm{~mm}$, reduced activity at $\mathrm{Ag}$ and $\mathrm{Au}$ ), Alcaligenes sp. AzoEpi21 (four metals, $\mathrm{CMC}_{\text {diff: }}: 4.7-12.3 \mathrm{~mm}$, affected at $\mathrm{Ag}$, $\mathrm{Au}, 50 \mathrm{mg} \mathrm{L}^{-1} \mathrm{Cr}$ and $\mathrm{Ni}$ ), Achromobacter sp. AzoEpi1 (4 metals, $\mathrm{CMC}_{\text {diff }}: 0.7-16.3 \mathrm{~mm}$, additional reduction at $\mathrm{Ag}, \mathrm{Au}, \mathrm{Cd} \mathrm{1,} \mathrm{Ni} \mathrm{50,} \mathrm{and} \mathrm{Pb} 1000 \mathrm{mg} \mathrm{L}^{-1}$ ), Acinetobacter sp. AzoEndo8 (3 metals, $\mathrm{CMC}_{\text {diff: }}: 1.3-11.3 \mathrm{~mm}$, low activity at $\mathrm{Ag}$, $\mathrm{Au}$, and $\mathrm{Ni}$, additionally affected at $\mathrm{Pb}$ $200 \mathrm{mg} \mathrm{L}^{-1}$ ), Agrobacterium sp. AzoEpi18 (two metals- $\mathrm{Cd}$ and $\mathrm{Pb}, \mathrm{CMC}_{\text {diff }}: 4-12.7 \mathrm{~mm}$, affected at $\mathrm{Cd} 10 \mathrm{mg} \mathrm{L}^{-1}$ ), Micrococcus sp. AzoEndo7 (two metals- $\mathrm{Cd}$ and $\mathrm{Ni}, \mathrm{CMC}_{\text {diff: }}$ : 1.3-21 mm, strong reduction at $\mathrm{Cr}, \mathrm{CMC}_{\text {diff }}:-15.7 \mathrm{~mm}$ ), Bacillus sp. AzoEndo3 (active at $\mathrm{Pb} 200-500 \mathrm{mg} \mathrm{L}^{-1}, \mathrm{CMC}_{\text {diff }}$ up to $5 \mathrm{~mm}, \mathrm{Cd} 5-10 \mathrm{mg} \mathrm{L}^{-1}, \mathrm{CMC}_{\text {diff }}$ up to $2.7 \mathrm{~mm}$ ), and Staphylococcus sp. AzoEndo11 (active only at $\mathrm{Pb} 200-1000 \mathrm{mg} \mathrm{L}^{-1}, \mathrm{CMC}_{\text {diff }}$ up to $8.7 \mathrm{~mm}$ ). 


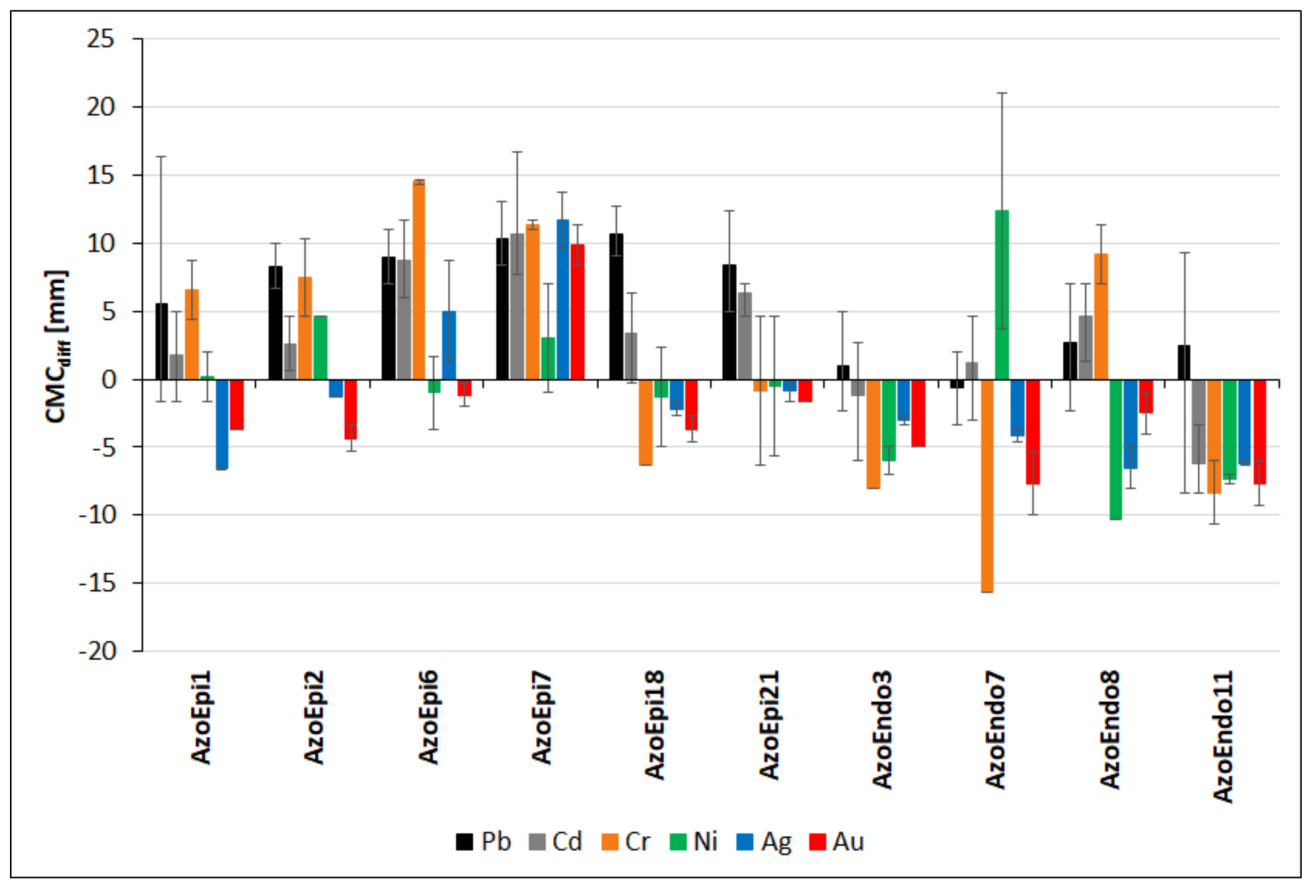

Figure 6. Effect of the metals applied in the specified range of doses (in $\mathrm{mg} \mathrm{L}^{-1}$ ) on the cellulolytic activities of the selected strains expressed as differences in the size of halos (in $\mathrm{mm}$ ) vs. the untreated control. Positive values of bars - stimulation of the activity; negative values of bars-inhibition of the activity. Positive whisker-maximum difference; negative-minimum. See Table 1 for strain codes.

The studied isolates displayed various phenotypes in terms of their potential for xylan degradation. In the presence of $\mathrm{Pb}, 4$ out of the 10 strains exhibited higher decomposition of xylan in relation to the control $(p<0.01)$. The highest average $\mathrm{XYL}_{\text {diff }}$ was recorded for Achromobacter sp. AzoEpi1 (6.4 mm), followed by Micrococcus sp. AzoEndo7 (3.4 mm), Bacillus sp. AzoEpi2, and Acinetobacter sp. AzoEndo8 (both $1.8 \mathrm{~mm}$ ). However, reduced decomposition rates were noted in the $1000 \mathrm{mg} \mathrm{Pb} \mathrm{L}^{-1}$ treatments (Supplementary Figure S2). The strongest inhibition of xylanase activity was noted for Delftia sp. AzoEpi7 $(-12.5 \mathrm{~mm})$ and Staphylococcus sp. AzoEndo11 $(-15.1 \mathrm{~mm})$ at all metal doses (Figure 7, Supplementary Figure S2). The exposure to $\mathrm{Cd}$ had a strong negative effect on xylan degradation in all strains (Figure 7). Achromobacter sp. AzoEpi1, Bacillus sp. AzoEpi2, Delftia sp. AzoEpi7, Micrococcus sp. AzoEndo7, and Staphylococcus sp. AzoEndo11 showed the strongest enzymatic inhibition $\left(\mathrm{XYL}_{\mathrm{diff}}<-10 \mathrm{~mm}(p<0.01\right.$, Figure 7). Bacillus sp. AzoEndo3 was the least affected, as it exhibited stimulation at $0.5\left(\mathrm{XYL}_{\mathrm{diff}}: 2 \mathrm{~mm}\right)$ and $1 \mathrm{mg} \mathrm{Cd} \mathrm{L}^{-1}\left(\mathrm{XYL}_{\text {diff: }}: 11.3 \mathrm{~mm}\right)(p<0.001$, Supplementary Figure S2). Cr also negatively influenced the xylanolytic ability of the studied strains. The most sensitive strains were Achromobacter sp. AzoEpi1, Bacillus sp. AzoEpi2, Delftia sp. AzoEpi7, and Staphylococcus sp. AzoEndo11 exhibiting XYL $\mathrm{L}_{\text {diff }}<-10 \mathrm{~mm}(p<0.001$, Figure 7). Alcaligenes sp. AzoEpi21, in turn, was the only strain displaying increased xylan degradation ability at the exposure to $50 \mathrm{mg} \mathrm{Cr} \mathrm{L}^{-1}(p<0.001$, Supplementary Figure S2). In the presence of Ni, only 3 out of the 10 strains exhibited positive average values of $\mathrm{XYL}_{\text {diff }}-$ Achromobacter sp. AzoEpi1 $(10 \mathrm{~mm})$, Bacillus sp. AzoEpi2 (5.3 mm), and Micrococcus sp. AzoEndo7 (3.7 mm). There were two strains showing the highest inhibition of xylan degradation, namely Delftia sp. AzoEpi7 $(-10 \mathrm{~mm})$ and Staphylococcus sp. AzoEndo11 $(-12.4 \mathrm{~mm})(p<0.001$, Figure 7). There was no significant dose effect on the observed strains responses $(p=0.11$, Supplementary Figure S2). The studied strains showed various responses to Ag. Five of them, namely Achromobacter sp. AzoEpi1, Bacillus sp. AzoEpi2, Microbacterium sp. AzoEpi6, Delftia sp. AzoEpi7, and Alcaligenes sp. AzoEpi21, were able to decompose xylan more efficiently than the non-treated strains $(p<0.01)$. Microbacterium sp. AzoEpi6 (XYL $\left.\mathrm{Liff}_{\mathrm{f}}: 10.5 \mathrm{~mm}\right)$ was the most efficient strain, while Acinetobacter sp. AzoEndo8 and Staphylococcus sp. AzoEndo11 
showed much lower potential $X Y L_{\text {diff }} \mathrm{s}<-10 \mathrm{~mm}(p<0.01$, Figure 7). Alcaligenes sp. AzoEpi21 and Micrococcus sp. AzoEndo7 showed negative differences at $5 \mathrm{mg} \mathrm{Ag} \mathrm{L}{ }^{-1}$ $(p<0.001$, Supplementary Figure S2). During the exposure to Au, only Achromobacter sp. AzoEpi1 and Delftia sp. AzoEpi7 exhibited positive values of $\mathrm{XYL}_{\text {diff }}-4.7$ and $3.5 \mathrm{~mm}$, respectively $(p<0.001$, Figure 7$)$. In turn, the highest negative value was recorded for Micrococcus sp. AzoEndo7 (XYL diff: $-11.8 \mathrm{~mm}$ ). No effect of $5 \mathrm{mg} \mathrm{Au} \mathrm{L}{ }^{-1}$ was demonstrated in the case of Acinetobacter sp. AzoEndo8 and Staphylococcus sp. AzoEndo11, while an average difference of xylanase activity of 0 was recorded for Bacillus sp. AzoEpi2 (Supplementary Figure S2).

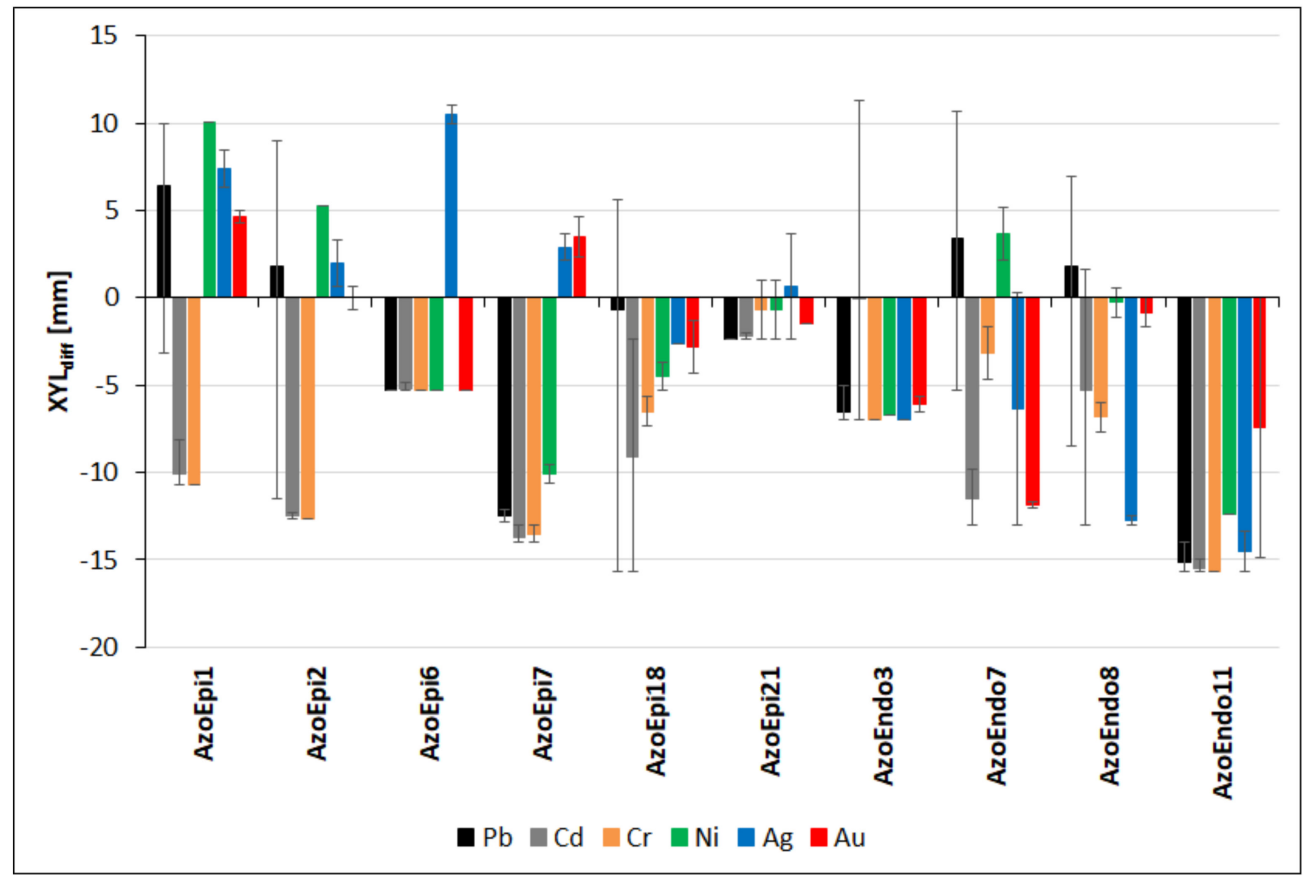

Figure 7. Effect of the metals applied in the specified range of doses (in $\mathrm{mg} \mathrm{L}^{-1}$ ) on the xylanolytic activities of the selected strains expressed as differences in the size of halos (in $\mathrm{mm}$ ) vs. the untreated control. Positive values of bars-stimulation of the activity; negative values of bars-inhibition of the activity. Positive whisker-maximum difference; negative-minimum. See Table 1 for strain codes.

In summary, the tested metals had strong and negative effects on the xylanolytic activity of the selected strains allowing us to categorize them and identify resistant and sensitive phenotypes. Achromobacter sp. AzoEpi1 was the most resistant strain, as it was able to produce more xylanase in the presence of four metals $\left(\mathrm{XYL}_{\text {diff }}=4.3-11.3 \mathrm{~mm}\right.$, activity inhibited only in the Cd treatment). It was followed by Bacillus sp. AzoEpi2 (four metals, $\mathrm{XYL}_{\text {diff }}=0.7-9 \mathrm{~mm}$, affected by Cd, Cr, and $10 \mathrm{mg} \mathrm{Au}$ and $1000 \mathrm{mg} \mathrm{Pb} \mathrm{L}^{-1}$ ), Micrococcus sp. AzoEndo7 (2 metals- $\mathrm{Pb}, \mathrm{Ni}$; $\mathrm{XYL}_{\text {diff }}=4.8-10.7 \mathrm{~mm}$, affected by $100 \mathrm{mg} \mathrm{Ni}$ and $1000 \mathrm{mg}$ $\mathrm{Pb} \mathrm{L}^{-1}$ ), Acinetobacter sp. AzoEndo8 (three doses of $\mathrm{Pb}$ and one dose of $\mathrm{Cd}$ and $\mathrm{Ni}$, $\mathrm{XYL}_{\text {diff }}=1.7-7 \mathrm{~mm}$ ), Delftia sp. AzoEpi7 (two metals-Ag, $\mathrm{Au} ; \mathrm{XYL}_{\text {diff }}=2.2-4.7 \mathrm{~mm}$ ), and Microbacterium sp. AzoEpi6 (one metal: Ag; $\mathrm{XYL}_{\text {diff }}=10-11 \mathrm{~mm}$ ). Alcaligenes sp. AzoEpi21, Agrobacterium sp. AzoEpi18, and Bacillus sp. AzoEndo3 showed some activities in single treatments $\left(X Y L_{\text {diff }}=1,2.33-5.67\right.$, and 2.3-11.3 mm, respectively), while Staphylococcus sp. AzoEndo11 displayed reduction of xylanolytic activity in all treatments.

\subsection{Proteolytic Activities in the Presence of Heavy Metals}

The heavy metals had a significant effect on the potential of the studied strains for use of proteins, resulting in various phenotypes. The exposure to $\mathrm{Pb}$ led to stimulation of proteolytic activities in relation to the control in the case of 3 endophytic strains: Micrococcus sp. AzoEndo7, Acinetobacter sp. AzoEndo8, and Staphylococcus sp. AzoEndo11 (PROT diff: 4.6, 
4.8 , and $2.3 \mathrm{~mm}$, respectively). In these strains, significant inhibition of protease activity was observed at $1000 \mathrm{mg} \mathrm{Pb} \mathrm{L}^{-1}(p<0.01$, Supplementary Figure S3). The other strains exhibited lower proteolytic activities in comparison to the control $(p<0.001)$. Achromobacter sp. AzoEpi1 exhibited slightly higher activities than in the control $\left(\mathrm{PROT}_{\text {diff }}=0.2-1.0 \mathrm{~mm}\right)$ and negative $\left(-2.7 \mathrm{~mm}\right.$ ) at $1000 \mathrm{mg} \mathrm{Pb} \mathrm{L}^{-1}$ (Supplementary Figure S3). The lowest difference of $-9.7 \mathrm{~mm}$ was recorded for Agrobacterium sp. AzoEpi18 (Figure 8). In the case of $\mathrm{Cd}, 3$ out of the 10 strains showed positive values of PROTdiff, i.e., Micrococcus sp. AzoEndo7 and Acinetobacter sp. AzoEndo8 exhibited differences of 2.5-2.8 mm ( $p>0.05)$ and Microbacterium sp. AzoEpi6-0.08 mm. The strongest inhibition of proteases was caused by Agrobacterium sp. AzoEpi18 ( PROT $_{\text {diff }}=-7.6 \mathrm{~mm}, p<0.001$, Figure 8). The lowest differences were recorded at $10 \mathrm{mg} \mathrm{Cd} \mathrm{L}^{-1}$ in the case of all strains (Supplementary Figure S3). During the exposure to $\mathrm{Cr}$, three strains exhibited increased proteolytic activities. The highest positive PROT diff of $7.8 \mathrm{~mm}$ was recorded for Alcaligenes sp. AzoEpi21, while the most negative value of $-7.8 \mathrm{~mm}$ was noted for Bacillus sp. AzoEndo3 $(p<0.01$, Figure 8). In the case of Microbacterium sp. AzoEpi6 and Delftia sp. AzoEpi7, negative and positive differences were noted at $100 \mathrm{mg} \mathrm{Cr} \mathrm{L}^{-1}$ and $50 \mathrm{mg} \mathrm{Cr} \mathrm{L}^{-1}$, respectively $(p<0.01$, Supplementary Figure S3). The exposure to Ni led to identification of three strains with stimulated proteolytic activity to maximum PROT $_{\text {diff }}$ of $3.0 \mathrm{~mm}$ in the case of Achromobacter sp. AzoEpi1. However, negative differences were observed for all strains at $100 \mathrm{mg} \mathrm{Ni} \mathrm{L}^{-1}$ $(p<0.001$, Supplementary Figure S3). Bacillus sp. AzoEndo3 exhibited the strongest inhibition of protease (PROT diff $:-11.5 \mathrm{~mm}, p<0.001$, Figure 8$)$. The noble metals had strong inhibiting effect on proteolytic activities; in the case of $\mathrm{Ag}$, all strains exhibited varying negative differences $(p<0.01$, Figure 8$)$. Acinetobacter sp. AzoEndo 8 was the most resistant (PROT diff: $-1 \mathrm{~mm}$ ) and Agrobacterium sp. AzoEpi18 was the most sensitive (PROT diff: $_{\text {: }}$ $-11.3 \mathrm{~mm}$ ). There were no significant effects of the Ag dose on the recorded differences ( $p=0.146$, Supplementary Figure S3). In the case of Au, only Microbacterium sp. AzoEpi6 displayed increased enzymatic activity $\left(\mathrm{PROT}_{\text {diff }}: 1.5 \mathrm{~mm}\right)$. The other strains exhibited significantly lower values ranging from -2.5 to $-11.3 \mathrm{~mm}(p<0.001$, Figure 8$)$. In most cases, the inhibition was dose-related $(p<0.001$, Supplementary Figure S3).

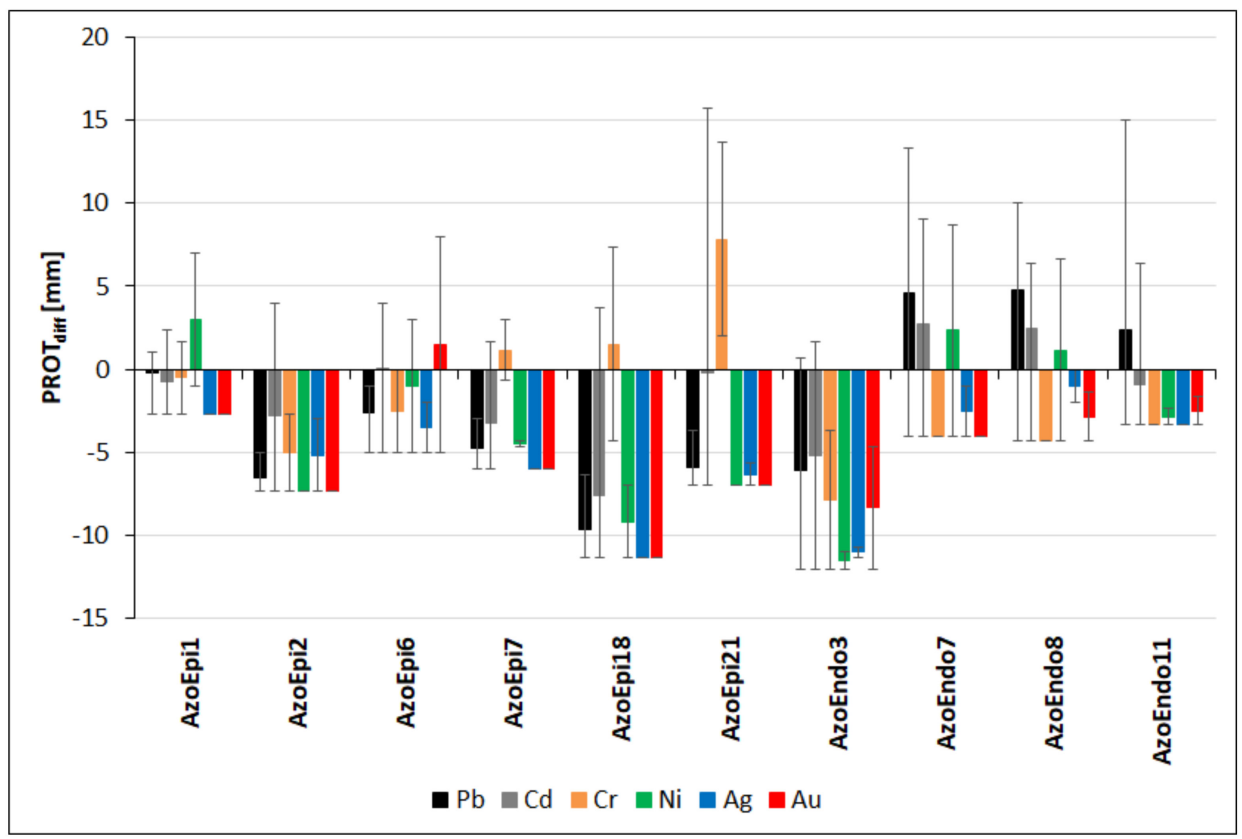

Figure 8. Effect of the metals applied in the specified range of doses (in $\mathrm{mg} \mathrm{L}^{-1}$ ) on the proteolytic activities of the selected strains expressed as differences in the size of halos (in $\mathrm{mm}$ ) vs. the untreated control. Positive values of bars—stimulation of the activity; negative values of bars-inhibition of the activity. Positive whisker-maximum difference; negative-minimum. See Table 1 for strain codes. 
To summarize, we found that all metals had very strong negative effects on the proteolytic activity. It was inhibited by $\mathrm{Ag}$ and $\mathrm{Au}$ in all strains with the exception of Microbacterium sp. AzoEpi6 (Au treatment). In addition, the analysis of the calculated differences allowed us to classify the strains according to their metabolic sensitivity (protease) to the studied metals, which allowed identification of various phenotype shifts. Based on the differences, we found the highest resistance of Micrococcus sp. AzoEndo7 and Acinetobacter sp. AzoEndo8 showing proteolytic activity in treatments with three metals $\left(\right.$ PROT $_{\text {diff }}=2.7-13.3$ and 3.7-10 mm, respectively). Microbacterium $\mathrm{sp}$. AzoEpi6 was the third most resistant strain, as it was the only one to show increased activity at $5 \mathrm{mg} \mathrm{Au} \mathrm{L}^{-1}$ and in single treatments with $\mathrm{Cd}$ and $\mathrm{Ni}\left(\mathrm{PROT}_{\text {diff }}=3-8 \mathrm{~mm}\right)$. Alcaligenes sp. AzoEpi21 and Agrobacterium sp. AzoEpi18 showed activities in both $\mathrm{Cr}$ treatments and at the single $\mathrm{Cd}$ dose $\left(\mathrm{PROT}_{\text {diff }}=2-15.7\right.$ and $3.7-7.3 \mathrm{~mm}$, respectively). They were followed by Delftia sp. AzoEpi7 $\left(\right.$ PROT $\left._{\text {diff }}=1.7-3 \mathrm{~mm}\right)$, Achromobacter sp. AzoEpi1 (PROT $_{\text {diff }}=0.3-7 \mathrm{~mm}$, low potential in treatments with three metals), and Staphylococcus sp. AzoEndo11 (PROT $_{\text {diff }}=1-15 \mathrm{~mm}$, one metal). Both Bacillus sp. strains showed stimulation of proteolytic activities only at 0.5 and $5 \mathrm{mg} \mathrm{Cd} \mathrm{L}^{-1}\left(\mathrm{PROT}_{\text {diff }}=1.7-4 \mathrm{~mm}\right)$.

\section{Discussion}

Determination of microbial responses to HM stress in terms of metabolism switching is important for the elucidation of the possible role of microorganisms in supporting plants in unfavorable conditions. This study made it possible to screen the phenotype switching possibilities of the analyzed bacteria as metabolic traits, which can help to elucidate their niche adaptation [4]. Although there have been many such studies, not all microbes have been tested yet under exposure to $\mathrm{Pb}, \mathrm{Cd}, \mathrm{Cr}, \mathrm{Ni}, \mathrm{Ag}$, and $\mathrm{Au}$. Most studies have only focused on recognition of the PGP potential of newly isolated microbes [11-16]. We aimed to reveal this unexplored field to find new potentially metal-tolerant species with concurrent PGP traits. In the presence of pollutants, microbial activity may be altered, leading to a switch of bacterial metabolic pathways [17], probably due to the enormous plasticity of the bacterial genome.

In our study, all strains exhibited the activities of the analyzed enzymes. However, metal stress caused changes in their effectiveness, i.e., phenotype switching. Heavy metals are key drivers of microbial response in terms of phytohormone synthesis and the potential for decomposition of the main constituents of pathogen cells (Cell Wall Degrading Enzymes, CWDE) $[6,17,18]$. Since metals are often parts of enzymes, their presence may increase enzymatic activity, stimulating plant growth. However, elevated levels of HMs may negatively affect metabolic pathways, lowering metabolism and causing adverse effects to organisms $[7,18]$. IAA is known to be a regulator that stimulates cell elongation and division, leading to enhanced plant growth. Several factors are involved in auxin metabolism under HM stress: PIN1 protein (auxin efflux carrier), ethylene (stimulation of IAA transport), nitrogen (II) oxide (transport repressor), antioxidant enzymes (activated at HM stress by an auxin conjugate), and hemicellulose (auxins enhance the content of hemicelluloses, which bind metals) [18]. This demonstrates how the microbial phenotype may change in terms of auxin synthesis in the presence of HMs. When a plant is exposed to heavy metals, its auxin level decreases; however, endosymbiotic bacteria can re-supply it and promote plant growth in unfavorable conditions [18]. Cellulose and hemicellulose are important fractions of biomass, being the first and second largest components of lignocellulosic biomass, with a ratio of 40.6-51.2\% and 28.5-37.2\%, respectively. Efficient degradation of this complex material requires the synergistic action of a group of biocatalysts, including cellulase and endoxylanase [19]. For this reason, it is important to study both enzymes to see microbial efficiency in cell wall decomposition. Many bacteria and fungi produce hydrolytic enzymes targeting organic polymers present in soil and water as well as being part of living organisms. Hence, the enzymatic action of microorganisms allows the elimination of pathogenic organisms by damaging their cell walls and participating in carbon and nitrogen cycling. 
In our study, we aimed to reveal the ability of the $A$. filiculoides microbiome to mitigate pollutants (organics and HMs) and its PGP potential. For this purpose, we combined phenotyping with PGP tests to detect changes in bacterial phenotypes in stress conditions. Microorganisms showing high plasticity are highly valuable in bioremediation of polluted sites and enhancement of plant production.

The most metal-resistant Agrobacterium sp. AzoEpi18 showed reduced synthesis of IAA in relation to the control conditions in the $\mathrm{Cd}$ treatment and moderate IAA production in the Ag treatment. This strain showed the highest synthesis of auxin $\left(12.89-22.26 \mu \mathrm{g} \mathrm{mL}^{-1}\right)$, which is similar to the values presented in a study conducted by Woźniak and co-authors [20], i.e., up to $22.51 \mu \mathrm{g} \mathrm{mL}^{-1}$ produced by endophytes. Mashiguchi and co-workers [21] showed that Agrobacterium tumefaciens enhanced the biosynthesis of IAA when introduced into tomato plants. Similar effects were presented for Agrobacterium radiobacter showing tolerance to $\mathrm{Pb}, \mathrm{Cd}, \mathrm{Zn}$, and $\mathrm{Cu}$ [22]. The capability of Agrobacterium sp. AzoEpi18 of cellulose degradation was mostly reduced. Higher activities were recorded only in the presence of all concentrations of $\mathrm{Pb}$, and lower levels were detected at $0.5-5 \mathrm{mg} \mathrm{Cd} \mathrm{L}^{-1}$. Xylanase activity was strongly inhibited by the analyzed metals except for $100-500 \mathrm{mg} \mathrm{Pb} \mathrm{L}^{-1}$. Increased proteolytic activity of Agrobacterium sp. AzoEpi18 was demonstrated in the $5 \mathrm{mg} \mathrm{Cd} \mathrm{L}^{-1}$ and $50 \mathrm{mg} \mathrm{Cr} \mathrm{L}^{-1}$ treatments. This strain showed greater efficiency of use of amino acids as a source of carbon and energy than sugars and carboxylic acids. The analysis of the growth conditions of the strain showed that the cells only proliferated at $\mathrm{pH}$ 6, but surprisingly efficient growth was identified at all sodium chloride concentrations tested (1-8\%). The data of the GEN III MicroPlates ${ }^{\mathrm{TM}}$ indicate that Agrobacterium sp. AzoEpi18 has metabolic pathways that allow this strain to grow in the presence of lithium chloride, potassium tellurite, sodium bromate, aztreonam, guanidine $\mathrm{HCl}$, and $1 \%$ sodium lactate. Unfortunately, this strain cannot be used in an environment contaminated with tetrazolium blue, tetrazolium violet, Niaproof 4 and Tween 40 surfactants, as well as drugs and antibiotics, as this strain has not been shown to be able to use these compounds.

The highly metal-resistant Achromobacter sp. AzoEpi1 exhibited slight changes in terms of IAA synthesis only at $5 \mathrm{mg} \mathrm{Ag} \mathrm{L}^{-1}$ in relation to the control. Cellulase activity was stimulated in the presence of four of the tested metals ( $\mathrm{Pb}, \mathrm{Cd}, \mathrm{Cr}$, and $\mathrm{Ni}$ ). In terms of xylanolytic activity, Achromobacter sp. showed the highest stimulation in the presence of three metals in the full range of doses ( $\mathrm{Ni}, \mathrm{Ag}$, and $\mathrm{Au}$ ) and at $100-500 \mathrm{mg} \mathrm{Pb} \mathrm{L}^{-1}$. Xylan degradation was inhibited by $\mathrm{Cd}$ and $\mathrm{Cr}$. The potential for protein decomposition was only reduced in the presence of the noble metals and $1000 \mathrm{mg} \mathrm{Pb} \mathrm{L}^{-1}, 5 \mathrm{mg} \mathrm{Cd} \mathrm{L}^{-1}$, and $50 \mathrm{mg}$ $\mathrm{Cr}$ and $\mathrm{Ni} \mathrm{L}^{-1}$. The metabolic patterns of the Achromobacter sp. AzoEpi1 strain indicate its similarity to the Agrobacterium sp. AzoEpi18, except that the former strain is capable of metabolizing troleandomycin, methyl pyruvate, and gelatin.

Microbacterium sp. AzoEpi6 exhibited slight stimulation of IAA release in the $\mathrm{Cr}$ (50 $\left.\mathrm{mg} \mathrm{L}^{-1}\right)$ and $\mathrm{Cd}\left(10 \mathrm{mg} \mathrm{L}^{-1}\right)$ treatments. Coretto and co-workers [23] demonstrated production of plant growth promoting compounds and tolerance to $\mathrm{Zn}, \mathrm{Cd}$, and $\mathrm{Pb}$ in Microbacterium sp. In addition, the strain had increased cellulase activity in the presence of four metals (all doses of $\mathrm{Pb}, \mathrm{Cd}, \mathrm{Cr}$, and $\mathrm{Ag}$ ) and $100 \mathrm{mg} \mathrm{Ni} \mathrm{L}^{-1}$. However, the xylanolytic activity of this strain was strongly reduced, with stimulation only in the Ag treatments. An increase in proteolytic ability was demonstrated in the case of $1-5 \mathrm{mg} \mathrm{Cd} \mathrm{L}^{-1}, 50 \mathrm{mg} \mathrm{Ni} \mathrm{L}^{-1}$, and $5 \mathrm{mg} \mathrm{Au} \mathrm{L}^{-1}$. The GEN III MicroPlates ${ }^{\mathrm{TM}}$ data for Microbacterium sp. AzoEpi6 indicated its high metabolic (phenotypic) similarity to the two strains discussed previously (Achromobacter sp. AzoEpi1 and Agrobacterium sp. AzoEpi18).

We did not detect any IAA synthesis by Alcaligenes sp. AzoEpi21; however, the strain Alcaligenes isolated by Fatima and co-workers produced this auxin under salinity stress, with an increase to $33.92 \mu \mathrm{g} \mathrm{mL}^{-1}$ at $700 \mathrm{mM} \mathrm{NaCl}$ [16]. All doses of $\mathrm{Pb}$ and Cd stimulated cellulose degradation by this strain, while the noble metals and the lower doses of $\mathrm{Cr}$ and Ni inhibited this activity. The heavy metals had a negative effect on xylan degradation, with the exception of $100 \mathrm{mg} \mathrm{Pb} \mathrm{L}^{-1}$ and $50 \mathrm{mg} \mathrm{Cr} \mathrm{L}^{-1}$. During the exposure to both doses of $\mathrm{Cr}(\mathrm{VI})$, Alcaligenes sp. exhibited higher proteolytic activity than in the control variant. 
Similar observations were recorded for $5 \mathrm{mg} \mathrm{Cd} \mathrm{L}^{-1}$. Our results have indicated that this strain probably prefers amino acids as carbon and energy sources and, to a lesser extent, carboxylic acids and carbohydrates. The Alcaligenes sp. AzoEpi21 has shown efficient growth at $\mathrm{pH} 6$ at the concentration of the sodium chloride solutions tested. The Biolog GEN III MicroPlates ${ }^{\mathrm{TM}}$ analysis revealed the presence of metabolic pathways allowing removal of aztreonam, glucuronamide, D-Salicin, Tween 40 , and 1\% sodium lactate from the environment.

$\mathrm{Cr}$ (VI) contributed to elevated production of IAA by Acinetobacter sp. AzoEndo8 in comparison to the control. Its cellulolytic activity was completely reduced in the presence of three metals $\left(\mathrm{Ni}, \mathrm{Ag}\right.$, and $\mathrm{Au}$ ) and $500 \mathrm{mg} \mathrm{Pb} \mathrm{L}^{-1}$. The xylanolytic activity of Acinetobacter sp. was strongly affected by the tested metals; it was only stimulated by the $100-500 \mathrm{mg} \mathrm{Pb} \mathrm{L}^{-1}, 1 \mathrm{mg} \mathrm{Cd} \mathrm{L}^{-1}$, and $50 \mathrm{mg} \mathrm{Ni} \mathrm{L}^{-1}$ treatments. The potential of Acinetobacter sp. AzoEndo8 for stronger protease degradation was noted for $\mathrm{Pb}\left(100-500 \mathrm{mg} \mathrm{L}^{-1}\right)$, $\mathrm{Cd}\left(0.5-5 \mathrm{mg} \mathrm{L}^{-1}\right)$, and $50 \mathrm{mg} \mathrm{Ni} \mathrm{L}^{-1}$. Wang and co-workers [19] tested the activity of xylanase XynA isolated from Bacillus sp. KW1 exposed to different physical and chemical factors. They noted $18 \%$ inhibition of the activity in the presence of Ni. This strain, like most of the tested strains, was tolerant to $\mathrm{pH}$ and salt concentration. Acinetobacter sp. AzoEndo8 is similar to Achromobacter sp. AzoEpi1 and Microbacterium sp. AzoEpi6 in terms of the ability to metabolize gelatin.

Delftia sp. AzoEpi7 was one of the strains showing IAA production in natural conditions (1.46-16.69 $\left.\mathrm{g} \mathrm{mL}^{-1}\right)$. Woźniak and co-authors [20] also presented IAA production by various Delftia sp. strains ranging between 1.02 and $22.51 \mu \mathrm{g} \mathrm{mL}^{-1}$. In our study, the presence of $\mathrm{Au}\left(5 \mathrm{mg} \mathrm{L}^{-1}\right)$ and $\mathrm{Cr}\left(100 \mathrm{mg} \mathrm{L}^{-1}\right)$ had strong effects on IAA production by Delftia sp. in comparison to the absence of any metal, but this was only visible for a short time. A study conducted by Morel and co-workers [24] reported IAA production by Delftia sp. JD2 only at $4 \mathrm{mg} \mathrm{Cr}$ (VI) $\mathrm{L}^{-1}$, while no auxin was detected at $100 \mathrm{mg} \mathrm{Cr} \mathrm{L}^{-1}$. Delftia sp. AzoEpi7 exhibited stimulation of cellulolytic activity in the case of 5 metals (all doses) and at $100 \mathrm{mg} \mathrm{Ni} \mathrm{L}^{-1}$, which makes it the best-adapted strain in our study. The xylanolytic activity of AzoEpi7 was strongly reduced and only the presence of the noble metals stimulated it above the levels in the control. In the case of Delftia sp., increased protease activity was noted during the exposure to $1 \mathrm{mg} \mathrm{Cd} \mathrm{L}^{-1}$ and $50 \mathrm{mg} \mathrm{Cr} \mathrm{L}^{-1}$.

This strain has a very interesting phenotype profile and expression thereof. On the one hand, Delftia sp. AzoEpi7 tolerates a smaller range of $\mathrm{pH}$ factors or sodium chloride concentrations; on the other hand, it has the ability to degrade essential antibiotics: lincomycin, vancomycin, and minocycline as well as other substances: Niaproof 4 , tetrazolium blue, and tetrazolium blue.

A positive effect of IAA on plant growth was demonstrated in Sedum alfredi Hance in the presence of endophytic Bacillus fluorescens Sasm5. Moreover, this bacterium possesses metal transporters: ZRT/IRT-like protein (ZIP) and heavy metal ATPase (HMA) participating in $\mathrm{Cd}$ uptake and translocation, which indicates that the bacterium directly regulates the expression of putative key $\mathrm{Cd}$ uptake and transport genes to enhance $\mathrm{Cd}$ accumulation in plants [25]. Fatima and Ahmed [26] demonstrated the potential of Sporosarcina saromensis and two strains of Bacillus cereus to stimulate the growth of Helianthus annuus L. exposed to $\mathrm{Cr}(\mathrm{VI})$ by production of auxin. He and co-workers [27] suggested that two strains of Bacillus sp., QX8 and QX13, exhibited strong resistance to $\mathrm{Cd}$ and $\mathrm{Pb}$ and produced IAA. In our study, however, neither strain of Bacillus sp. showed any IAA synthesis, but both grew well in the presence of these metals. Similar findings were presented by $\mathrm{Yu}$ and coauthors [28] and Efe [29], where not all Bacillus strains produced this auxin. The effect of Au on IAA was studied by Panichikkal and co-workers [30]. In their study, gold nanoparticles (AuNPs) synthesized by Bacillus subtilis SJ15 were introduced into the growing medium of Pseudomonas monteilii and Vigna unguiculata. The study showed increased production of IAA by the bacterium at $50 \mu \mathrm{g} \mathrm{mL}^{-1}$ AuNPs and enhanced the growth of the plant. Kumar and co-workers [31] conducted a similar study using silver NPs and Bacillus cereus LPR2 and showed positive effects of both factors on maize growth. The cellulolytic activity of 
Bacillus sp. AzoEndo3 was stimulated only at $200-500 \mathrm{mg} \mathrm{Pb} \mathrm{L}^{-1}$ and $5-10 \mathrm{mg} \mathrm{Cd} \mathrm{L}^{-1}$, while $\mathrm{Cr}, \mathrm{Ni}, \mathrm{Ag}$, and Au had inhibiting effects. The epiphytic Bacillus sp. exhibited increased cellulose degradation at the exposure to $\mathrm{Pb}, \mathrm{Cd}, \mathrm{Cr}$, and $\mathrm{Ni}$ and inhibition thereof by the noble metals. The potential for xylan degradation in Bacillus sp. AzoEpi2 was higher in the presence of $\mathrm{Ni}, \mathrm{Ag}, 100-500 \mathrm{mg} \mathrm{Pb} \mathrm{L}^{-1}$, and $5 \mathrm{mg} \mathrm{Au} \mathrm{L}^{-1}$. The exposure to $\mathrm{Cd}$ and Cr inhibited this activity. In the case of the endophytic Bacillus sp., only $0.5-1 \mathrm{mg} \mathrm{Cd} \mathrm{L}^{-1}$ had a positive effect on the potential for xylan degradation, whereas the other treatments had an inhibiting effect. Strong inhibition of xylanolytic activity of Bacillus GESF-1 in the presence of $\mathrm{Hg}^{2+}, \mathrm{Fe}^{3+}, \mathrm{Cu}^{2+}, \mathrm{Cd}^{2+}$, and $\mathrm{Zn}^{2+}$ was demonstrated by Menon et al. [12]. The proteolytic activity of this strain was higher in the control only at 0.5 and $5 \mathrm{mg} \mathrm{Cd} \mathrm{L}-1$. The epiphytic Bacillus AzoEpi2 displayed the lowest proteolytic activity, as the positive effect of the presence of metals was only observed at $5 \mathrm{mg} \mathrm{Cd} \mathrm{L}^{-1}$. A study carried out by Sumardi and co-workers [32] demonstrated the inhibiting effects of $\mathrm{Ca}, \mathrm{Cu}$, and $\mathrm{Fe}$ on proteolytic activity. In contrast, the activity was strongly stimulated in the presence of $\mathrm{Mn}$ (II); moreover, additional application of magnetic field with the addition of $\mathrm{FeCl}_{3}$ had a positive effect.

Staphylococcus sp. AzoEndo11 produced $21.55 \mu \mathrm{g} \mathrm{mL} \mathrm{m}^{-1} \mathrm{IAA}$ in the $\mathrm{Pb}$ treatment after the prolonged exposure but not in the control. However, this microbe was proved to produce auxin at a higher level of $38.8 \mu \mathrm{g} \mathrm{mL}^{-1}$ [13]. In addition, its cellulase activity was inhibited most strongly (five metals), as it was higher only at $200-1000 \mathrm{mg} \mathrm{Pb} \mathrm{L}^{-1}$ in comparison to the control. This was the only strain exhibiting the complete reduction of xylan degradation in all metal treatments. In the case of proteolytic activity, a positive effect on the amount of decomposed protein was only recorded in the $200-500 \mathrm{mg} \mathrm{Pb} \mathrm{L}^{-1}$ and $0.5 \mathrm{mg} \mathrm{Cd} \mathrm{L}^{-1}$ treatments.

The Biolog GEN III MicroPlates ${ }^{\mathrm{TM}}$ analysis of this strain is extremely interesting. This is the only strain that can grow at $\mathrm{pH} \mathrm{5,} \mathrm{and} \mathrm{also} \mathrm{in} \mathrm{the} \mathrm{tested} \mathrm{sodium} \mathrm{chloride} \mathrm{range}$ $(1-8 \%)$. This strain cannot grow in the presence of lithium chloride. Among the possible environmental pollutants, this strain only shows the ability to metabolize aztreonam, troleandomycin, nalidixic acid, and $1 \%$ sodium lactate.

Micrococcus sp. AzoEndo7 was the most sensitive to the tested metals; however, this strain showed the strongest switch in terms of IAA synthesis. It produced no IAA under control conditions. Nevertheless, the exposure to $\mathrm{Ag}\left(10 \mathrm{mg} \mathrm{L}^{-1}\right), \mathrm{Cr}$ (both doses), $\mathrm{Pb}$ (100-500 $\left.\mathrm{mg} \mathrm{L}^{-1}\right)$, and $5 \mathrm{mg} \mathrm{Au} \mathrm{L}^{-1}$ induced strong/intermediate production of the phytohormone. High production of IAA equal to $154.3 \mu \mathrm{g} \mathrm{mL} \mathrm{m}^{-1}$ by Micrococcus aloeverae DCB-20 was demonstrated by Ahamd and co-workers [33], who indicated the high potential of this microorganism to promote plant growth. The ability of Micrococcus sp. AzoEndo7 to degrade cellulose was reduced by $\mathrm{Cr}, \mathrm{Ag}$, $\mathrm{Au}$ (all doses), and $1 \mathrm{mg} \mathrm{Cd} \mathrm{L}^{-1}$ but enhanced by $500 \mathrm{mg} \mathrm{Pb} \mathrm{L}^{-1}$, both doses of $\mathrm{Ni}$, and three doses of $\mathrm{Cd}$. The xylanolytic activity of Micrococcus sp. AzoEndo7 was strongly affected by the tested metals; it was only stimulated in the $100-500 \mathrm{mg} \mathrm{Pb} \mathrm{L}^{-1}$ and $50 \mathrm{mg} \mathrm{Ni} \mathrm{L}^{-1}$ treatments. Higher potential for protease degradation was recorded for $\mathrm{Pb}\left(100-500 \mathrm{mg} \mathrm{L}^{-1}\right), \mathrm{Cd}\left(0.5-5 \mathrm{mg} \mathrm{L}^{-1}\right)$, and $50 \mathrm{mg} \mathrm{Ni} \mathrm{L}^{-1}$. This strain had the lowest degree of use of carbohydrates, amino acids, and carboxylic acids. Interestingly, it exhibited extremely low growth at $\mathrm{pH} 5$ and 6, which makes it necessary to extend the research to test bacterial growth at different $\mathrm{pH}$. Micrococcus sp. AzoEndo7 turned out to be tolerant to the inorganic compounds used. Unfortunately, this strain showed no or extremely low tolerance to drugs, surfactants, organic compounds, and dyes.

Mendoza-Hernández et al. [34] demonstrated that the initial production of IAA by strains isolated from the plant rhizosphere was low (up to $11.5 \mu \mathrm{g} \mathrm{mL}^{-1}$ ) and strongly affected by the presence of heavy metals. They noted strong stimulation of IAA synthesis in the presence of $\mathrm{Cu}, \mathrm{Pb}$, and $\mathrm{As}$, while exposure to $\mathrm{Ni}, \mathrm{Cr}, \mathrm{Cd}$, and $\mathrm{Mn}$ had inhibiting effects. Besides heavy metals, we tested the effects of $\mathrm{Ag}$ and $\mathrm{Au}$. An earlier study showed that silver nitrate (V) may both block ethylene, which inhibits the synthesis of IAA, and promote auxin efflux from roots resulting in low levels of the phytohormone [35]. Haddad and co- 
workers [36] demonstrated inhibited cellulase activity in clay and sandy soil contaminated with $\mathrm{Cd}, \mathrm{Co}, \mathrm{Ni}$, and $\mathrm{Pb}$. Kandler and co-workers [37] found that soil microbial activity, including cellulases, xylanases, and proteases, was slightly affected by $\mathrm{Zn}, \mathrm{Cu}, \mathrm{Ni}, \mathrm{V}$, and $\mathrm{Cd}$ in comparison to enzymes involved in $\mathrm{N}, \mathrm{P}$, and $\mathrm{S}$ cycling.

During the exposure to $\mathrm{Pb}$, all the epiphytes increased their potential to degrade cellulose, while the endophytes showed only stimulation at some doses of $\mathrm{Pb}$. The analysis of enzymatic activity in paddy and corn fields polluted with $\mathrm{Pb}, \mathrm{Cd}, \mathrm{Cu}$, and $\mathrm{Zn}$ indicated that HMs inhibited cellulolytic activity in more polluted paddy fields [38]. In the presence of Cd, five epiphytes (except for Agrobacterium sp. AzoEpi18) and Acinetobacter sp. AzoEndo8 developed larger halos than in the control, while the other strains showed only partial stimulation at several doses. Achromobacter sp. AzoEpi1, Bacillus sp. AzoEpi2, Microbacterium sp. AzoEpi6, and Delftia sp. AzoEpi7 and Acinetobacter sp. AzoEndo8 exhibited stronger cellulolytic degradation in the presence of $\mathrm{Cr}$ (VI), whereas higher degradation by Alcaligenes sp. AzoEpi21 was recorded only at the higher doses of this metal. The activity of the three other endophytes and Agrobacterium sp. AzoEpi18 was reduced at the exposure to Cr. Aslam et al. [17] demonstrated inhibition of cellulase activity of Bacillus amyloliquefaciens-ASK11 during exposure to $\mathrm{Cr}$ (VI). This response was strongly related to the Cr-dose: the activity was 2 times lower at $50 \mathrm{mg} \mathrm{L}^{-1}, 4$ times lower at $100 \mathrm{mg} \mathrm{L}^{-1}$ and 10 times lower at $250 \mathrm{mg} \mathrm{L}^{-1}$ and higher doses than in the untreated control [17]. In our study, the endophytic Bacillus sp. exhibited lower CMC-activity in the presence of $\mathrm{Cr}$, but the epiphytic strain showed increased production of the enzyme in comparison to the control. Ni had a more negative effect on cellulose degradation, as only Achromobacter sp. AzoEpi1 and Bacillus sp. AzoEpi2 showed increased activity in the whole range of the metal concentration, Microbacterium sp. AzoEpi6, Delftia sp. AzoEpi7, and Alcaligenes sp. AzoEpi21 showed partial stimulation, and the four other strains displayed lower cellulolytic activity than in the control. The noble metals had strong negative effects on enzyme activity. Only Microbacterium sp. AzoEpi6 and Delftia sp. AzoEpi7 were stimulated to degrade more cellulose in the Ag (both strains) and Au treatments (Delftia sp.).

In general, the xylanolytic activity was reduced in most cases, and $\mathrm{Cd}$ and $\mathrm{Cr}$ had the strongest effects, affecting all strains except for Bacillus sp. AzoEndo3 (0.5-1 mg Cd L ${ }^{-1}$ ) and Alcaligenes sp. AzoEpi21 (50 mg Cr L $\left.{ }^{-1}\right)$. In the case of $\mathrm{Pb}$, lower activity was exhibited by Microbacterium sp. AzoEpi6, Delftia sp. AzoEpi7, and Alcaligenes sp. AzoEpi21, as well as Bacillus sp. AzoEndo3 and Staphylococcus sp. AzoEndo11, while the other strains showed partial potential for enhanced xylan degradation: Achromobacter sp. AzoEpi1, Bacillus sp. AzoEpi2, Agrobacterium sp. AzoEpi18, Acinetobacter sp. Micrococcus sp. AzoEndo7, and Acinetobacter sp. AzoEndo8-100-500 mg Pb L ${ }^{-1}$. The presence of $\mathrm{Ni}$ led to reduction of xylanase activity of five strains (Microbacterium sp. AzoEpi6, Delftia sp. AzoEpi7, Agrobacterium sp. AzoEpi18, Bacillus sp. AzoEndo3, and Staphylococcus sp. AzoEndo11), while Achromobacter sp. AzoEpi1 and Bacillus sp. AzoEpi2 exhibited stimulation of the activity. The other three strains, namely Alcaligenes sp. AzoEpi21, Micrococcus sp. AzoEndo7, and Acinetobacter sp. AzoEndo8, showed increased degradation at $100 \mathrm{mg} \mathrm{Ni} \mathrm{L}^{-1}$ (epiphyte) and $50 \mathrm{mg} \mathrm{Ni} \mathrm{L}^{-1}$ (both endophytes). In the case of the Ag treatments, 6 out of the 10 strains (Agrobacterium sp. AzoEpi18, Alcaligenes sp. AzoEpi21 and all endophytes) exhibited lower xylanase activity in comparison to the control. The exposure to Au revealed that two strains (Achromobacter sp. AzoEpi1 and Delftia sp. AzoEpi7) had higher activity in the whole range of doses, and Bacillus sp. AzoEpi2 degraded greater amounts of xylan at $5 \mathrm{mg} \mathrm{Au} \mathrm{L}{ }^{-1}$.

The overall analysis of proteolytic activities revealed the predominance of inhibiting effects of the tested metals. Only Alcaligenes sp. AzoEpi21 was able to degrade more proteins than in the control in the whole range of Cr (VI). In the treatment with this metal, AzoEpi1, AzoEpi7, and AzoEpi18 showed higher proteolytic potential at $50 \mathrm{mg} \mathrm{Cr} \mathrm{L}^{-1}$. Kheirabadi and co-workers [39] studied the ability of Shewanella sp. to remove Cr (VI). They found that the protease activity was very high $\left(>140 \mathrm{mg} \mathrm{mL}^{-1}\right)$ at $50 \mathrm{mg} \mathrm{Cr} \mathrm{L}^{-1}$ and 2-3 times 
lower at a higher concentration of the metal. The authors suggested that the presence of serine protease helps Shewanella sp. to cope with the metal. Ag had the most negative inhibitory effects on proteases in all strains. In the case of $\mathrm{Au}$, only Microbacterium sp. AzoEpi6 was able to decompose greater amounts of proteins at $5 \mathrm{mg} \mathrm{Au} \mathrm{L}^{-1}$. In the $\mathrm{Ni}$ treatment, only Achromobacter sp. AzoEpi1 and Microbacterium sp. AzoEpi6 as well as Micrococcus sp. AzoEndo7 and Acinetobacter sp. AzoEndo8 showed protease activity at $50 \mathrm{mg} \mathrm{Ni} \mathrm{L}^{-1}$. During the exposure to $\mathrm{Pb}$, five strains were able to decompose proteins partially (doses of $100-500 \mathrm{mg} \mathrm{L}^{-1}$ ) at higher amounts than in the control. These strains were all endophytes, and epiphytic Achromobacter sp. Cd was the only treatment in which all strains showed partial potential to produce more proteases ranging between 0.5 and $5 \mathrm{mg} \mathrm{Cd} \mathrm{L}{ }^{-1}$, depending on the strain. Li and co-workers [38] reported a stimulating effect of HMs on proteolytic activity. They concluded that such an effect was related to the presence of a higher pool of proteins derived from the degradation processes carried out by soil microorganisms.

\section{Conclusions}

Our results suggest that the bacterial isolates can have dual functions as a bioremediation agent and a potential plant growth promoting biofertilizer.

Delftia sp. AzoEpi7 displayed the highest phenotype change in our study-it was the most efficient in metabolizing carboxylic acids, surfactants (including persistent Niaproof 4), dyes, and other organic compounds and had the highest cellulolytic activity in the presence of five metals $(\mathrm{Pb}, \mathrm{Cd}, \mathrm{Cr}, \mathrm{Ag}$ and $\mathrm{Au})$. Staphylococcus sp. AzoEndo11 responded to three factors-it grew in the widest range of $\mathrm{pH}$ and efficiently metabolized antibiotics and inorganic compounds. Achromobacter sp. AzoEpi1 exhibited the highest xylanolytic and proteolytic potential in the $\mathrm{Ni}, \mathrm{Ag}$, and $\mathrm{Au}$ as well as $\mathrm{Pb}, \mathrm{Cd}$ and Ni treatments, respectively, and very high tolerance to $\mathrm{HMs}$-all doses except for $10 \mathrm{mg} \mathrm{Au} \mathrm{L}^{-1}$. Microbacterium sp. AzoEpi6 were characterized by the strongest metabolizing potential for carbohydrates and drugs, including $\mathrm{N}$-acetylneuraminic acid, which was difficult to degrade by the other strains. Agrobacterium sp. AzoEpi18 showed the highest tolerance to the tested metals (4 doses of $\mathrm{Pb}$ and all doses of $\mathrm{Cd}, \mathrm{Cr}, \mathrm{Ni}, \mathrm{Ag}$, and $\mathrm{Au}$ ) and degradation of amino acids. The fourth group comprised Alcaligenes sp. AzoEpi21 showing the highest tolerance to salinity stress and Micrococcus sp. AzoEndo7 with the highest changes in IAA during exposure to $\mathrm{Cr}, \mathrm{Ni}, \mathrm{Ag}$, and Au. Both Bacillus isolates and Acinetobacter sp. AzoEndo8 showed hardly any phenotype change during the exposure to the analyzed factors. Moreover, it should be noted that each strain has individual tolerance to the tested parameters or potential to metabolize specific compounds, which makes all strains beneficial as both biofertilizers and bioremediation agents, especially when combined in one biopreparation.

Supplementary Materials: The following are available online at https:/ /www.mdpi.com/article/10 $.3390 /$ biology10090879/s1, Supplementary Figure S1. Effect of the metals applied in the specified range of doses (in $\mathrm{mg} \mathrm{L}^{-1}$ ) on the cellulolytic activities of the selected strains expressed as differences in the size of halos (in mm) vs. the untreated control. Positive values of bars-stimulation of the activity; negative values of bars-inhibition of the activity. See Table 1 for strain codes, Supplementary Figure S2. Effect of the metals applied in the specified range of doses (in $\mathrm{mg} \mathrm{L}^{-1}$ ) on the xylanolytic activities of the selected strains expressed as differences in the size of halos (in $\mathrm{mm}$ ) vs. the untreated control. Positive values of bars-stimulation of the activity; negative values of bars-inhibition of the activity. See Table 1 for strain codes, Supplementary Figure S3. Effect of the metals applied in the specified range of doses (in $\mathrm{mg} \mathrm{L}^{-1}$ ) on the proteolytic activities of the selected strains expressed as differences in the size of halos (in $\mathrm{mm}$ ) vs. the untreated control. Positive values of bars-stimulation of the activity; negative values of bars-inhibition of the activity. See Table 1 for strain codes.

Author Contributions: Conceptualization, A.B. and A.K.; methodology, A.B. and A.K.; software, A.M.-G.; validation, A.B. and A.K.; formal analysis, A.B. and A.M.-G.; investigation, A.B. and A.M.G.; resources, A.B. and A.G.; data curation, A.B. and A.M.-G.; writing-original draft preparation, A.B., A.K. and A.G.; writing-review and editing, A.K., A.G. and A.W.; visualization, A.B., A.M.-G. 
and A.G.; supervision, A.B.; project administration, A.W.; funding acquisition, A.W. All authors have read and agreed to the published version of the manuscript.

Funding: This research was funded by the interdisciplinary grant of John Paul II Catholic University of Lublin (Poland), grant number 13/2019. The APC was funded by John Paul II Catholic University of Lublin (Poland).

Institutional Review Board Statement: Not applicable.

Informed Consent Statement: Not applicable.

Data Availability Statement: Data are contained within the article or supplementary material.

Conflicts of Interest: The authors declare no conflict of interest. The funders had no role in the design of the study; in the collection, analyses, or interpretation of data; in the writing of the manuscript, or in the decision to publish the results.

\section{References}

1. Rosier, A.; Medeiros, F.H.V.; Bais, H.P. Defining plant growth promoting rhizobacteria molecular and biochemical networks in beneficial plant-microbe interactions. Plant Soil 2018, 428, 35-55. [CrossRef]

2. Vandana, U.K.; Rajkumari, J.; Singha, L.P.; Satish, L.; Alavilli, H.; Sudheer, P.D.V.N.; Chauhan, S.; Ratnala, R.; Satturu, V.; Mazumder, P.B.; et al. The Endophytic Microbiome as a Hotspot of Synergistic Interactions, with Prospects of Plant Growth Promotion. Biology 2021, 10, 101. [CrossRef] [PubMed]

3. He, W.; Megharaj, M.; Wu, C.-Y.; Subashchandrabose, S.R.; Dai, C.-C. Endophyte-assisted phytoremediation: Mechanisms and current application strategies for soil mixed pollutants. Crit. Rev. Biotechnol. 2020, 40, 31-45. [CrossRef]

4. Acin-Albiac, M.; Filannino, P.; Gobbetti, M.; Di Cagno, R. Microbial high throughput phenomics: The potential of an irreplaceable omics. Comput. Struct. Biotechnol. J. 2020, 18, 2290-2299. [CrossRef]

5. Madsen, E.L. Microorganisms and their roles in fundamental biogeochemical cycles. Curr. Opin. Biotechnol. 2011, 22, 456-464. [CrossRef] [PubMed]

6. Nazli, F.; Mustafa, A.; Ahmad, M.; Hussain, A.; Jamil, M.; Wang, X.; Shakeel, Q.; Imtiaz, M.; El-Esawi, M.A. A Review on Practical Application and Potentials of Phytohormone-Producing Plant Growth-Promoting Rhizobacteria for Inducing Heavy Metal Tolerance in Crops. Sustainability 2020, 12, 9056. [CrossRef]

7. Nguyen, T.Q.; Sesin, V.; Kisiala, A.; Emery, R.J.N. Phytohormonal Roles in Plant Responses to Heavy Metal Stress: Implications for Using Macrophytes in Phytoremediation of Aquatic Ecosystems. Environ. Toxicol. Chem. 2021, 40, 7-22. [CrossRef] [PubMed]

8. Banach, A.M.; Banach, K.; Stępniewska, Z. Phytoremediation as a promising technology for water and soil purification: Azolla caroliniana Willd. As a case study. Acta Agrophysica 2012, 19, 241-252.

9. Banach, A.; Kuźniar, A.; Mencfel, R.; Wolińska, A. The Study on the Cultivable Microbiome of the Aquatic Fern Azolla Filiculoides L. as New Source of Beneficial Microorganisms. Appl. Sci. 2019, 9, 2143. [CrossRef]

10. Gordon, S.; Weber, R. Colorimetric estimation of indoleacetic acid. Plant Physiol. 1951, 26, 192-195. [CrossRef]

11. Karry, F.; Abdallah, M.B.; Kallel, N.; Hamza, M.; Fakhfakh, M.; Sayadi, S. Extracellular hydrolytic enzymes produced by halophilic bacteria and archaea isolated from hypersaline lake. Mol. Biol. Rep. 2018, 45, 1297-1309. [CrossRef]

12. Menon, G.; Mody, K.; Keshri, J.; Jha, B. Isolation, purification, and characterization of haloalkaline xylanase from a marine Bacillus pumilus strain, GESF-1. Biotechnol. Bioproc. E 2010, 15, 998-1005. [CrossRef]

13. Shahzad, R.; Waqas, M.; Khan, A.L.; Al-Hosni, K.; Kang, S.M.; Seo, C.W.; Lee, I.J. Indoleacetic acid production and plant growth promoting potential of bacterial endophytes isolated from rice (Oryza sativa L.) seeds. Acta Biol. Hung. 2017, 68, 175-186. [CrossRef] [PubMed]

14. Flimban, S.; Oh, S.-E.; Joo, J.H.; Hussein, K.A. Characterization and Identification of Cellulose-degrading Bacteria Isolated from a Microbial Fuel Cell Reactor. Biotechnol. Bioproc. E 2019, 24, 622-631. [CrossRef]

15. Knapik, K.; Becerra, M.; González-Siso, M.-I. Microbial diversity analysis and screening for novel xylanase enzymes from the sediment of the Lobios Hot Spring in Spain. Sci. Rep. 2019, 9, 11195. [CrossRef] [PubMed]

16. Fatima, T.; Mishra, I.; Verma, R.; Arora, N.K. Mechanisms of halotolerant plant growth promoting Alcaligenes sp. involved in salt tolerance and enhancement of the growth of rice under salinity stress. 3 Biotech 2020, 10, 361. [CrossRef]

17. Aslam, S.; Hussain, A.; Qazi, J.I. Production of Cellulase by Bacillus amyloliquefaciens-ASK11 Under High Chromium Stress. Waste Biomass Valor. 2019, 10, 53-61. [CrossRef]

18. Bücker-Neto, L.; Paiva, A.L.S.; Machado, R.D.; Arenhart, R.A.; Margis-Pinheiro, M. Interactions between plant hormones and heavy metals responses. Genet. Mol. Biol. 2017, 40, 373-386. [CrossRef]

19. Wang, K.; Cao, R.; Wang, M.; Lin, Q.; Zhan, R.; Xu, H.; Wang, S. A novel thermostable GH10 xylanase with activities on a wide variety of cellulosic substrates from a xylanolytic Bacillus strain exhibiting significant synergy with commercial Celluclast $1.5 \mathrm{~L}$ in pretreated corn stover hydrolysis. Biotechnol. Biofuels 2019, 12, 48. [CrossRef] 
20. Woźniak, M.; Gałązka, A.; Tyśkiewicz, R.; Jaroszuk-Ściseł, J. Endophytic Bacteria Potentially Promote Plant Growth by Synthesizing Different Metabolites and their Phenotypic/Physiological Profiles in the Biolog GEN III MicroPlateTM Test. Int. J. Mol. Sci. 2019, 20, 5283. [CrossRef]

21. Mashiguchi, K.; Hisano, H.; Takeda-Kamiya, N.; Takebayashi, Y.; Ariizumi, T.; Gao, Y.; Ezura, H.; Sato, K.; Zhao, Y.; Hayashi, K.; et al. Agrobacterium tumefaciens Enhances Biosynthesis of Two Distinct Auxins in the Formation of Crown Galls. Plant Cell Physiol. 2019, 60, 29-37. [CrossRef]

22. Fan, M.; Liu, Z.; Nan, L.; Wang, E.; Chen, W.; Lin, Y.; Wei, G. Isolation, characterization, and selection of heavy metal-resistant and plant growth-promoting endophytic bacteria from root nodules of Robinia pseudoacacia in a Pb/Zn mining area. Microbiol. Res. 2018, 217, 51-59. [CrossRef]

23. Corretto, E.; Antonielli, L.; Sessitsch, A.; Höfer, C.; Puschenreiter, M.; Widhalm, S.; Swarnalakshmi, K.; Brader, G. Comparative Genomics of Microbacterium Species to Reveal Diversity, Potential for Secondary Metabolites and Heavy Metal Resistance. Front. Microbiol. 2020, 11, 1869. [CrossRef] [PubMed]

24. Morel, M.A.; Ubalde, M.C.; Braña, V.; Castro-Sowinski, S. Delftia sp. JD2: A potential Cr(VI)-reducing agent with plant growth-promoting activity. Arch. Microbiol. 2011, 193, 63-68. [CrossRef] [PubMed]

25. Chen, B.; Luo, S.; Wu, Y.; Ye, J.; Wang, Q.; Xu, X.; Pan, F.; Khan, K.Y.; Feng, Y.; Yang, X. The Effects of the Endophytic Bacterium Pseudomonas fluorescens Sasm05 and IAA on the Plant Growth and Cadmium Uptake of Sedum alfredii Hance. Front. Microbiol. 2017, 8, 2538. [CrossRef] [PubMed]

26. Fatima, H.; Ahmed, A. Indole-3-acetic acid synthesizing chromium-resistant bacteria can mitigate chromium toxicity in Helianthus annuus L. Plant Soil Environ. 2020, 66, 216-221. [CrossRef]

27. He, X.; Xu, M.; Wei, Q.; Tang, M.; Guan, L.; Lou, L.; Xu, X.; Hu, Z.; Chen, Y.; Shen, Z.; et al. Promotion of growth and phytoextraction of cadmium and lead in Solanum nigrum L. mediated by plant-growth-promoting rhizobacteria. Ecotoxicol. Environ. Saf. 2020, 205, 111333. [CrossRef]

28. Yu, X.; Li, Y.; Zhang, C.; Liu, H.; Liu, J.; Zheng, W.; Kang, X.; Leng, X.; Zhao, K.; Gu, Y.; et al. Culturable Heavy Metal-Resistant and Plant Growth Promoting Bacteria in V-Ti Magnetite Mine Tailing Soil from Panzhihua, China. PLoS ONE 2014, 9, e106618. [CrossRef] [PubMed]

29. Efe, D. Potential Plant Growth-Promoting Bacteria with Heavy Metal Resistance. Potential Plant Growth-Promoting Bacteria with Heavy Metal Resistance. Curr. Microbiol. 2020, 77, 3861-3868. [CrossRef]

30. Panichikkal, J.; Roshmi, T.; Jimtha, J.J.; Radhakrishnan, E.K. Biogenic Gold Nanoparticle Supplementation to Plant Beneficial Pseudomonas monteilii was Found to Enhance its Plant Probiotic Effect. Curr. Microbiol. 2019, 76, 503-509. [CrossRef]

31. Kumar, P.; Pahal, V.; Gupta, A.; Vadhan, R.; Chandra, H.; Dubey, R.C. Effect of silver nanoparticles and Bacillus cereus LPR2 on the growth of Zea mays. Sci. Rep. 2020, 10, 20409. [CrossRef] [PubMed]

32. Agustrina, R.; Ekowati, C.N.; Pasaribu, Y.S. Characterization of protease from Bacillus sp. on medium containing $\mathrm{FeCl}_{3} \mathrm{exposed}$ to magnetic field $0.2 \mathrm{mt}$. IOP Conf. Ser. Earth Environ. Sci. 2018, 130, 012046. [CrossRef]

33. Ahmad, E.; Sharma, S.K.; Sharma, P.K. Deciphering operation of tryptophan-independent pathway in high indole-3-acetic acid (IAA) producing Micrococcus aloeverae DCB-20. FEMS Microbiol. Lett. 2020, 367, fnaa190. [CrossRef] [PubMed]

34. Mendoza-Hernández, J.C.; Perea-Vélez, Y.S.; Arriola-Morales, J.; Martínez-Simón, S.M.; Pérez-Osorio, G. Assessing the effects of heavy metals in ACC deaminase and IAA production on plant growth-promoting bacteria. Microbiol. Res. 2016, 188-189, 53-61. [CrossRef]

35. Strader, L.C.; Beisner, E.R.; Bartel, B. Silver ions increase auxin efflux independently of effects on ethylene response. Plant Cell 2009, 21, 3585-3590. [CrossRef]

36. Haddad, S.A.; Lemanowicz, J.; Abd El-Azeim, M.M. Cellulose decomposition in clay and sandy soils contaminated with heavy metals. Int. J. Environ. Sci. Technol. 2019, 16, 3275-3290. [CrossRef]

37. Kandeler, E.; Kampichler, C.; Horak, O. Influence of heavy metals on the functional diversity of soil microbial communities. Biol. Fertil. Soils. 1996, 23, 299-306. [CrossRef]

38. Li, Q.; Hu, Q.; Zhang, C.; Jin, Z. Effects of Pb, Cd, Zn, and Cu on Soil Enzyme Activity and Soil Properties Related to Agricultural Land-Use Practices in Karst Area Contaminated by Pb-Zn Tailings. Pol. J. Environ. Stud. 2018, 27, 2623-2632. [CrossRef]

39. Kheirabadi, M.; Mahmoodi, R.; Mollania, N.; Kheirabadi, M. Fast chromium removal by Shewanella sp.: An enzymatic mechanism depending on serine protease. Int. J. Environ. Sci. Technol. 2020, 17, 143-152. [CrossRef] 